\title{
A TAXONOMIC REVISION OF THE GENUS AMARACARPUS (RUBIACEAE, PSYCHOTRIEAE)
}

\author{
AARON P. DAVIS ${ }^{1} \&$ DIANE M. BRIDSON ${ }^{2}$
}

\begin{abstract}
SUMMARY
A taxonomic revision of Amaracarpus Blume (Rubiaceae, Psychotrieae) is presented. The salient characteristics of Amaracarpus are given, with particular attention to the differences between Amaracarpus, Dolianthus and Psychotria. The taxonomic account includes a key to species, an informal (artificial) subgeneric classification, full descriptions, and a list of specimens examined. Amaracarpus comprises 22 species: six new combinations are proposed, one new species is described, eight species are moved to other genera, the transfer of 12 species to Psychotria is confirmed, and numerous taxa are placed into synonymy. A checklist of all Amaracarpus names is provided.
\end{abstract}

Key words: Amaracarpus, Dolianthus, Psychotria, Psychotrieae, Rubiaceae, New Guinea, South East Asia.

\section{INTRODUCTION}

Amaracarpus Blume has been the subject of recent systematic debate (Nepokroeff et al., 1999; Andersson, 2002) and taxonomic confusion (e.g. Puff \& Wong, 1993). Generally, the salient features of the genus are poorly known or misunderstood and the genus has become a heterogeneous assemblage of species, which is known to include taxa from other genera (e.g. Smith, 1988; Fosberg \& Sachet, 1991). Recently, Davis \& Bridson (2001) reinstated the genus Dolianthus, and transferred 11 species of Amaracarpus to it. In this contribution we propose a revised taxonomy for Amaracarpus, representing the first taxonomic revision for Amaracarpus, and attempt to provide a more satisfactory delimitation of the genus. Of the 77 names in Amaracarpus we recognize 22 species. The remaining names are placed in the synonymy of Amaracarpus, designated to other genera (e.g. Lasianthus (Lasiantheae), Psychotria (Psychotrieae), and Saprosma (Paederieae)), or are of unknown placement (species unknown to us). A checklist of all taxa described in Amaracarpus is provided.

The salient features of Amaracarpus are: 1) branches with a distinctly horizontal orientation; 2) leaves arranged in the same plane as the branches; 3 ) shoots with a generally monopodial growth pattern (flowering does not significantly effect the architecture of the shoot); 4) stipules usually with two or (less often) one distinct setae, or stipules sometimes entire (rarely deeply bifid: only one species); 5) inflorescences "near axil-

1) Nationaal Herbarium Nederland, Universiteit Leiden branch, P.O. Box 9514, 2300 RA Leiden, The Netherlands. Present address: The Herbarium, The Royal Botanic Gardens, Kew, Richmond, Surrey, TW9 3AE, United Kingdom.

2) The Herbarium, The Royal Botanic Gardens, Kew, Richmond, Surrey, TW9 3AE, United Kingdom. 
lary' (flowers/inflorescences on very short side shoots or axillary brachyblasts (very condensed side shoots), or axillary; 6) flowers small, 4-merous; 7) corollas all white (or greenish); 8) filaments attached within the ring of internal corolla hairs (if hairs present); 9) fruits red (and containing two pyrenes); 10) pyrenes possessing marginal pre-formed germination slits (PGSs), which run along the inside margins of each pyrene for (1/2-)2/3 to the entire length; 11) endosperm entire; and 12) seed coat (testa) not staining red in the presence of $70 \%$ alcohol (SCP negative).

Dolianthus shares the same fruit morphology as Amaracarpus but differs in the following features: 1) branches mostly not distinctly horizontal; 2) leaves not arranged in the same plane as the branches; 3 ) shoots with a growth pattern generally sympodial (flowering influences shoot architecture); 4) stipules entire or minutely fimbriate (without obvious appendages); 5) inflorescences terminal to subterminal (overtopped); 6) flowers large and 5-merous; 7) corollas brightly coloured (usually bicoloured with blue and yellow); and 8) filaments attached above the ring of internal corolla throat hairs (if hairs present). Further information on Dolianthus is provided in Davis \& Bridson (2001).

Amaracarpus has often been associated (e.g. Sohmer, 1988; Nepokroeff et al., 1999) with Psychotria, a large (c. 2000 spp.) heterogeneous and taxonomically problematic genus (Andersson, 2002). Some authors have regarded Amaracarpus as a synonym of Psychotria (e.g. Fosberg \& Sachet, 1991; Nepokroeff et al., 1999). Indeed, some species of Psychotria share one or more salient characters found in Amaracarpus, as listed above, and the two genera may superficially resemble each other. However, the combination of characters listed above for Amaracarpus is not found in Psychotria or any other genus. Detailed information on the delimitation of Amaracarpus and Dolianthus, and closely related members of Psychotrieae, is given in Davis \& Bridson (in press).

Andersson (2002) has shown that Amaracarpus is most closely related to the Pacific/ Australasian members of the Psychotrieae (including: the ant plants (e.g. Hydnophytum), Calycosia, Dolianthus, Straussia, and New Guinea Psychotria species, and not Psychotria s.s. (fide Andersson, 2002; and see Davis et al., 2001).

Species delimitation in Amaracarpus is difficult and often problematic, particularly as the only data currently available is from morphological study. We have no data concerning the genetic basis of morphological traits, and their value for the classification of Amaracarpus. In this taxonomic treatment we place importance on stipule and inflorescence characters (see below: Subgeneric Division of Amaracarpus), simply because they seem to be the least influenced by the environment and appear to have the most taxonomic value. Leaf size and shape are highly variable; pubescence appears to have some taxonomic value, although it is still somewhat variable within species. Polymorphism in leaf morphology, and to a certain extent inflorescence morphology (e.g. see Valeton, 1927) seems to have lead to the recognition of too many species. Increased field collection since previous studies of Amaracarpus (e.g. Valeton, 1927; Merrill \& Perry, 1946) has illuminated the significant variation in these characters. Many species based on quite subtle, or often apparently quite distinct differences in leaf morphology (particularly size and shape) have been synonymized in the taxonomic treatment presented here. In a similar manner Fosberg \& Sachet (1991) reduced 11 Pacific Amaracarpus to two species of Psychotria. 
In this taxonomic treatment we recognize 22 species, which we believe is based upon a species concept that is neither narrow nor broad but somewhere in between. A narrow species concept would lead to recognition of perhaps more than 60 species, but this would make the taxa very difficult to delimit and identify. A broad species delimitation would probably result in about 10 species or less, but again we feel this would make species highly polymorphic and very difficult to identify. We also believe that a formal classification based on a broad species concept would not satisfactorily record the natural (and potentially discrete) variation within the genus. When there are more collections for South East Asia and particularly New Guinea we believe that further taxonomic changes will be inevitable. Our instinct at the moment is that the number of species is more likely to increase, and where possible we have highlighted species (see Notes) where further taxonomic division may be necessary.

Amaracarpus distribution is centred in New Guinea (Papua Barat (formerly Irian Jaya) and Papua New Guinea) and all but two of the 22 species occur there. One species, A. pubescens, is very widespread, extending from the Indian Ocean (Seychelles and Christmas Islands), through SE Asia, to Papua Barat, with a subspecies (A. pubescens subsp. microphyllus) in the Philippines and Moluccas. Two species (A. attenuatus, A. grandifolius) extend to the Solomon Islands, and one species (A. heteropus) reaches Australia (NE Queensland). Two species are endemic to the Moluccas. Five species, A. anomalus, A. brassii, A. doormaniensis, A. grandifolius, and A. xanthocarpus, have limited distributions.

Amaracarpus grows at altitudes ranging from 0-2800 m, but (unlike Dolianthus) only a few species (A. brassii, and perhaps A. compactus and A. novo-guineensis) can be considered true alpines $(>2500 \mathrm{~m})$.

\section{MATERIALS AND METHODS}

Herbarium material was consulted from the following herbaria: A, B, BM, BO, CANB, JCT, K, L, NSW, NY, QRS, SING, SYD, US, WRSL. The measurements, colours and other details given in the descriptions are based on herbarium specimens, or data derived from field notes. Habitat and ecology, uses, and vernacular names are derived from herbarium labels; where such data are not recorded, the relevant category titles have been omitted from the revision text. Figures 2, 3, 4, and 5 have been reproduced from Nova Guinea 8, 3 (1909-1914) with modification (e.g. removal of inaccurately drawn structures).

A database of Amaracarpus specimens is available on request from the authors.

\section{CONSERVATION ASSESSMENTS}

Amaracarpus are generally widespread, and most are recorded from two or more countries or islands. As such, most Amaracarpus are assumed not to be in danger of extinction and should be placed in the Least Concern (LC) category of the IUCN Red List Category criteria (IUCN, 2001). Some species of Amaracarpus, however, occur in two countries but have a limited distribution, and other species have very limited distributions (within a single region of from one location only). Species falling into this category include: A. anomalus, A. brassii, A. doormaniensis, A. grandifolius, and 
A. xanthocarpus. At the moment we consider the above species to be Data Deficient (DD), although we would like to highlight them as needing further study to ascertain whether they are in danger of extinction.

\title{
TAXONOMIC TREATMENT
}

\section{DESCRIPTION OF THE GENUS}

\begin{abstract}
AMARACARPUS
Amaracarpus Blume (1826) 954. - Type: Amaracarpus pubescens Blume. Neoschimpera Hemsl. (1906) t. 2810. - Type: Neoschimpera heterophylla Hemsl.
\end{abstract}

Shrubs, treelets, or trees, distinctly horizontally branched with leaves distinctly arranged in one plane, each branch sometimes resembling a bipinnate or tripinnate fern frond; short side shoots present and often conspicuous, usually bearing smaller leaves than the main shoots, the first leaf pair often smaller than those immediately above; secondary axillary side shoots (axillary brachyblasts) usually present, often greatly reduced and consisting of 1-2(-4) leaf pair(s), with leaves $1 / 2$ to $1 / 3$ smaller than the normal shoot leaves, sometimes making the branch appear superficially anisophyllous. Branches terete, glabrous to hirsutellous. Branchlets \pm terete. Stipules caducous to semi-persistent, leaving a simple naked scar, distinctly sheathing, connate for c. 1/2 their length or more (and forming a tube), or free (when mature), membranous to chartaceous, glabrous to pubescent, apex truncate to acute but with ( 1 or) 2 prominent setae on the upper margin, or apex acute and entire, rarely very deeply bifid, setae usually continuing along the length of the stipule to the base as a raised line or ridge. Leaves: petiolate or sometimes \pm sessile; leaf blades chartaceous to subcoriaceous; abaxial surface: secondary veins \pm straight or slightly curved, linked by an undulating intramarginal vein (brochidodromous) and sometimes with a second (but much fainter) intramarginal vein closer to the margin, venation openly reticulate to branched. Inflorescences terminal on axillary brachyblasts ('near-axillary'), axillary (axillary brachyblasts greatly reduced or absent), or sometimes terminal on side shoots, subtended by reduced leaves (see habit) or sometimes only by small bract-like leaves of the axillary brachyblast and stipules; near-axillary and axillary inflorescences in 1 or 2 axil(s) per node, when 2 per node opposite in leaf axils; usually 1 inflorescence per leaf axil, rarely 2 or more, usually 1-flowered or 3-several-flowered (simple cymes or small compound racemes), sessile or pedunculate, usually erect, rarely pendent; bracts present or absent, if present at the apex of peduncle(s) or inflorescence axis/axes, subtending pedicels or sometimes the flower(s); bracteoles present or absent, if present at the apex of pedicel(s), directly subtending the flower(s). Flowers heterostylous, 4-merous, sessile to shortly pedicellate, \pm glabrous. Calyx (incl. hypanthium) campanulate to cupuliform; calyx limb (tube) shorter than the lobes, calyx lobes usually deltate to triangular; apices acute or sometimes rounded. Corolla tube mostly shortly cylindrical, but also cylindrical, funnel-shaped, or campanulate, subequal to lobes or distinctly exceeding them, white or whitish, rarely (or in bud) green tinged; external surface glabrous or hairy, internal surface with a ring of white or whitish hairs in the upper (short-styled flowers) or middle upwards (long- 
styled flowers) part of the throat, or internal surface glabrous, corolla lobes deltate to triangular, \pm equal to much shorter than the tube, reflexed at maturity, apices thickened, acute to obtuse. Stamens 4, inserted at the top (short-styled flowers) or lower down, as far as the middle area (long-styled flowers) of the corolla tube, included (mostly longstyled flowers) or exserted to well-exserted (mostly short-styled flowers), fixed within the ring of hairs (if present); anthers dorsifixed, introrse, \pm sessile, narrowly ellipsoid to \pm linear, yellow, whitish or brown; filaments usually $<1 \mathrm{~mm}$ long, white or whitish. Ovary 2-locular, each locule with a single erect ovule. Disc hemi-globose, slightly 4-lobed or entire, glabrous. Style filiform; stigma composed of 2 flattened-linear lobes, or 2 linear to ellipsoid lobes, usually divaricate, exserted (long-styled) or included (shortstyled), white or whitish. Infructescence erect to subpendent on the underside of the branchlets (pedunculate species only). Fruit a small drupe, containing 2 pyrenes, rather fleshy, ellipsoid to ellipsoid-obovoid, or rarely globose, usually no more than c. $7 \mathrm{~mm}$ long, with 6-8 longitudinal ridges running along its length (i.e. conspicuously ribbed) or \pm smooth, glabrous or very rarely pubescent (only A. grandifolius var. trichocarpus), green to yellowish when immature, orange to red when mature, drying brown; calyx limb and lobes usually persistent; disc persistent. Pyrenes elliptic to elliptic-obovate or rarely circular in outline (only A.acuminatus), apex rounded, base cuneate; abaxial surface convex, each pyrene with 3 or 4 ridges or sometimes \pm smooth; adaxial surface flat, smooth, with preformed germination slits (PGSs) running along the inside margins of each pyrene for (1/2-)2/3 to the entire length. Seeds the same shape as the pyrenes, but slightly smaller, 3 by $2 \mathrm{~mm}$; seed coat smooth, not staining red or reddish in alcohol; endosperm homogenous, pale coloured.

Distribution - Indian Ocean (Seychelles, Christmas Islands); SE Asia, New Guinea (Papua Barat and Papua New Guinea, incl. New Britain and New Ireland), Australia (NE Queensland) and western Pacific (Solomon Islands).

Habitat \& Ecology - An understorey plant of evergreen humid forest (incl. primary, disturbed and secondary forest), rarely in coastal scrub (A. nymanii).

\section{KEY TO THE SPECIES}

Notes on using key. Before using this key it is worthwhile to establish the presence/absence or certain salient characters. It is useful to determine whether: 1) the inflorescence is sessile or pedunculate; 2) the stipules have one or two setae (bristle-like point(s)), or none (stipule apex obtuse to acute, without appendages). It is necessary to examine several stipules, and preferably as many as a dozen or more, before a confident assessment of stipule morphology can be made.

It is important to use mature leaves when taking measurements for the key, and to ensure that only those of the main shoot (and not leaves of the short side shoots and axillary brachyblasts) are used (see generic description for details).

1a. Inflorescences pedunculate, $(1-) 3-7(-8)$-flowered $\ldots \ldots \ldots \ldots \ldots \ldots \ldots 2$

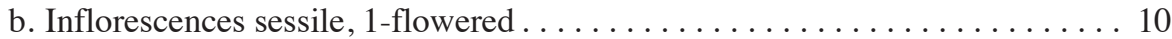

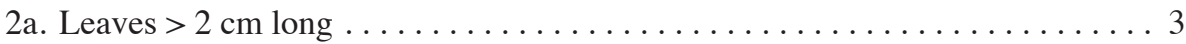

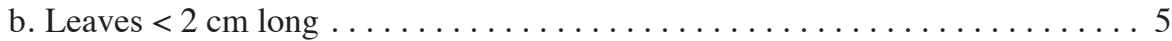

3a. Leaves usually $>4.5 \mathrm{~cm}$ long, secondary veins $>8$ pairs $\ldots \ldots \ldots \ldots \ldots$

b. Leaves $<4.5 \mathrm{~cm}$ long, secondary veins $<8$ pairs $\ldots \ldots \ldots \ldots \ldots$ 20. A. major

4a. Stipules with 2 setae. Leaves usually with $8-10$ pairs of secondary veins . . . . . 
b. Stipules deeply bifid, divided into two narrowly triangular points. Leaves usually with $10-14$ pairs of secondary veins . . . . . . . . . 22. attenuatus

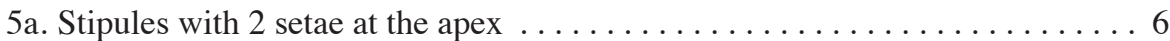

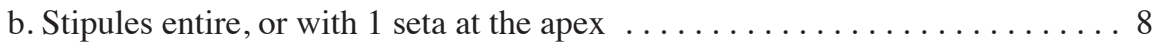

6a. Inflorescences sessile . . . . . . . . . xanthocarpus

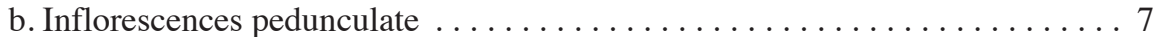

7a. Inflorescences (2- or) 3-flowered $\ldots \ldots \ldots \ldots \ldots \ldots \ldots$ 17. A. acuminatus

b. Inflorescences 1 -flowered $\ldots \ldots \ldots \ldots \ldots \ldots \ldots$ 18. A. doormaniensis

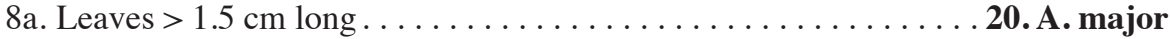

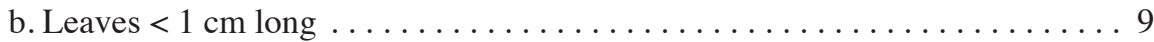

9a. Inflorescences pedunculate, peduncle $0.4-1.3 \mathrm{~cm}$ long . . . 17. A. acuminatus

b. Inflorescences sessile, or peduncle $<0.1-0.3 \mathrm{~cm}$ long . . 21. A. idenburgensis

10a. Leaves usually $>2.5 \mathrm{~cm}$ long, secondary veins usually $>5$ pairs . . . . . 11

b. Leaves usually $<2.5 \mathrm{~cm}$ long, secondary veins usually $<5$ pairs . . . . . . 13

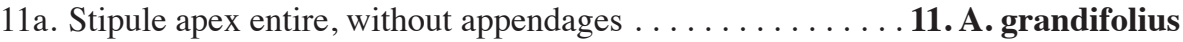

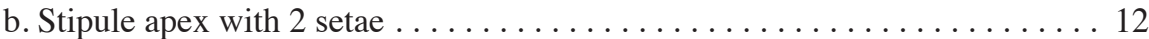

12a. Leaves usually drying grey or greyish, midrib hirsutellous to pubescent, rarely glabrous, secondary veins hirsutellous to pubescent or sometimes glabrous ....

1a. A. pubescens subsp. pubescens

b. Leaves drying green, midrib glabrous to puberulous, secondary veins glabrous to

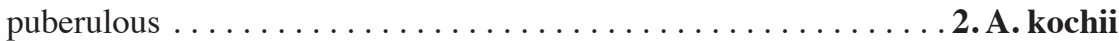

13a. Corolla usually $>\left(10_{-}\right) 13 \mathrm{~mm}$ long $\ldots \ldots \ldots \ldots \ldots$. A. grandiflorus

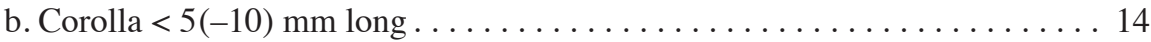

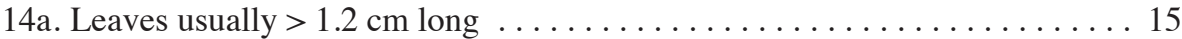

b. Leaves usually $<1 \mathrm{~cm}$ long $\ldots \ldots \ldots \ldots \ldots \ldots \ldots \ldots \ldots \ldots \ldots \ldots$

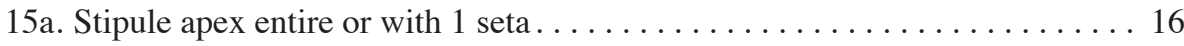

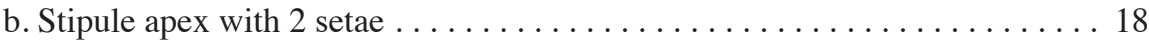

16a. Leaf blades \pm elliptic to narrowly elliptic or narrowly ovate, rarely narrowly ob-

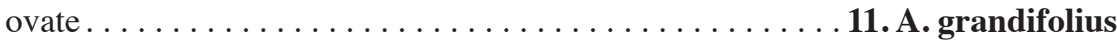

b. Leaf blades obovate to narrowly obovate or obovate-elliptic, rarely narrowly el-

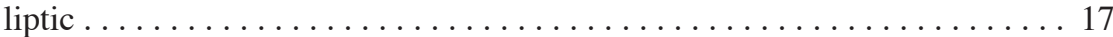

17a. Branchlets glabrous to pubescent, rarely hirsutellous. Brachyblasts usually few. Leaves not conspicuously congested ........... 12. A. wichmannii

b. Branchlets hirsutellous to pubescent. Brachyblasts usually numerous. Leaves

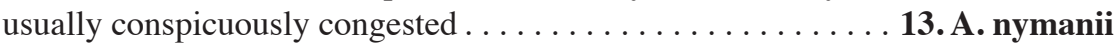

18a. Leaves rather irregularly arranged along branchlets, forming \pm flat but \pm irregular tiers. . . . . . . . . . . . . . . . . . . . . . . . . . . . .

b. Leaves regularly arranged in the same plane as the branchlets, forming flat but

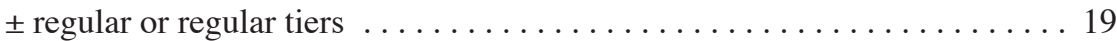

19a Leaves well spaced, forming irregular shaped tiers (in outline). Petioles usually $>1 \mathrm{~mm}$ long $\ldots \ldots \ldots \ldots \ldots \ldots$ 1b. A. pubescens subsp. microphyllus

b. Leaves close together, forming regular shaped tiers (in outline). Petioles usually

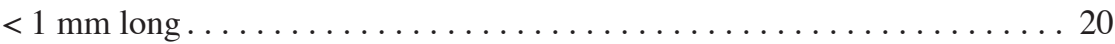

20a. Axillary brachyblasts few to numerous. Stipule setae c. $1 \mathrm{~mm}$ long, glabrous to pubescent

3. A. papuanus 
b. Axillary brachyblasts few to absent. Stipule setae $2-3 \mathrm{~mm}$ long, puberulous ... $\ldots \ldots \ldots \ldots \ldots \ldots \ldots \ldots \ldots \ldots \ldots \ldots \ldots \ldots \ldots \ldots \ldots$. A. schlechteri

21a. Leaves $\leq 2 \mathrm{~mm}$ long, cordate to deltate, or almost reniform. Stipules with 2

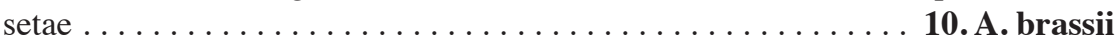

b. Leaves $>4 \mathrm{~mm}$ long, variously shaped but not cordate, deltate or reniform. Stipules

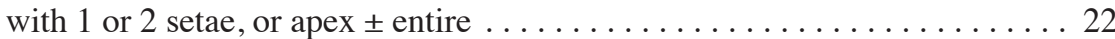

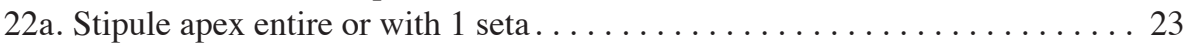

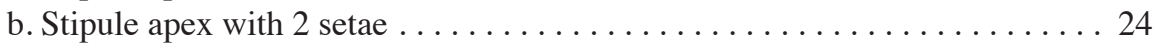

23a. Stipule apex entire $\ldots \ldots \ldots \ldots \ldots \ldots \ldots \ldots \ldots \ldots \ldots$ 14. A. novo-guineensis

b. Stipule apex entire or with 1 or 2 short tuft of hairs or sometimes with 1 seta . 15. A. compactus

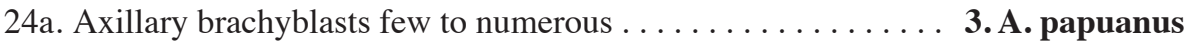

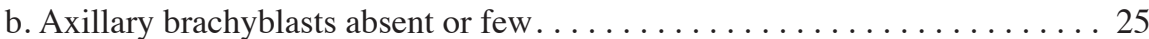

25a. Branching pattern rather irregular. Leaves congested on side shoots, not distinctly arranged in the same plane. Corollas puberulous or glabrous on the external

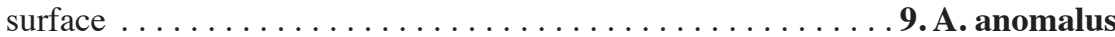

b. Branching pattern regular. Leaves \pm evenly spaced on side shoots, distinctly arranged in the same plane. Corollas glabrous on the external surface . . . . 26

26a. Leaves $0.4-1.3(-2.2) \mathrm{cm}$ long, but generally $>7 \mathrm{~mm}$ long, venation manifest to

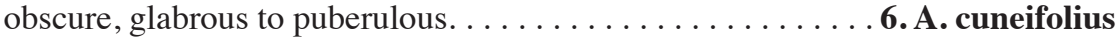

b. Leaves (0.3-)0.4-0.9(-1.2) cm long, but generally $<7 \mathrm{~mm}$ long, venation obscure to invisible, glabrous

8. A. belensis

\section{SUBGENERIC DIVISION OF AMARACARPUS}

We have not attempted to devise a formal subgeneric classification for Amaracarpus and consider that to do so without further supporting systematic data would be meaningless, or at best preliminary. Instead we propose two informal species groups, the first with two subgroups and the second with three subgroups. It is suggested that these groups are used in conjunction with the key to assist species identifications.

SPECIES GROUP 1

Species with sessile, 1-flowered inflorescences (rarely 2- or 3-flowered)

Species subgroup 1a Stipule apex with 2 setae

1. A. pubescens Leaves usually $>1.5 \mathrm{~cm}$ long and usually $>2 \mathrm{~cm}$ long

2. A. kochii

3. A. papuanus Leaves usually $>1.2 \mathrm{~cm}$ long but usually $<2 \mathrm{~cm}$ long

4. A. schlechteri

5. A. calcicola

6. A. cuneifolius Leaves usually $<1 \mathrm{~cm}$ long but $>0.7 \mathrm{~cm}$ long

8. A. belensis Leaves usually $<0.9 \mathrm{~cm}$ long and often $<0.7 \mathrm{~cm}$ long

9. A. anomalus

10. A. brassii $\quad$ Leaves $<0.3 \mathrm{~cm}$ long 
Species subgroup 1b Stipule apex either entire or with 1 seta (both character states occur in some species)

11. A. grandifolius Leaves usually $>1 \mathrm{~cm}$ long and often $>3 \mathrm{~cm}$ long

12. A. wichmannii Leaves usually $>1 \mathrm{~cm}$ long but often $<2 \mathrm{~cm}$ long

13. A. nymanii

7. A. grandiflorus Leaves usually $<1 \mathrm{~cm}$ long but often $<0.8 \mathrm{~cm}$ long

14. A. novo-guineensis

15. A. compactus

SPECIES GROUP 2

Species with pedunculate inflorescences, and/or inflorescences consisting of simple or compound dichasial cymes, (1-)3-7(-8)-flowered

Species subgroup 2a Stipule apex with 2 setae

16. A. heteropus Leaves $>3 \mathrm{~cm}$ long and often $>5 \mathrm{~cm}$ long

17. A. acuminatus Leaves usually $0.5-1 \mathrm{~cm}$ long, always $<2 \mathrm{~cm}$ long

18. A. doormaniensis

19. A. xanthocarpus

Species subgroup 2b Stipule apex either entire or with 1 seta (both character states occur in some species)

20. A. major Leaves $>1.5 \mathrm{~cm}$ long but never $>4 \mathrm{~cm}$ long

21. A. idenburgensis Leaves $0.5-0.9 \mathrm{~cm}$ long

Species subgroup 2c Stipule apex deeply bifid (divided into two long narrowly triangular points)

22. A. attenuatus $\quad$ Leaves usually $4.5-11.5 \mathrm{~cm}$ long

\section{DESCRIPTION OF SPECIES AND NOMENCLATURE}

\section{Amaracarpus pubescens Blume - Fig. 1}

Amaracarpus pubescens Blume (1826) 954; Backer \& Bakh.f. (1965) 345; Du Puy (1993) 399.

- Type: Blume s.n. (holo L), Java, 'ad montem Menaram et prope Tugu Provinciae Buitenzorg ut etiam in Nusa Kambanga insula' [without date].

Psychotria ferruginea Baker (1877) 156. - Type: Horne 253 (holo K), Seychelles, Mahé, Sept. 1871.

Saprosma nativitatis Baker f. in Andrews (1900) 180. - Type: Andrews 79 (holo BM; iso K), Christmas Island, 1897-1898.

Neoschimpera heterophylla Hemsl. (1906) t. 2810. - Type: Thomasset 181 (holo K), Seychelles, Mahé, Mont Serbert Estate, 1300 ft [396 m], March 1905.

[Psychotria uniflora Reinw. in schedae (see Miq. (1857) 304).]

Treelet or shrub, $(0.45-) 0.6-1.5(-3) \mathrm{m}$ high, hirsutellous to pubescent, sometimes puberulous to glabrous, hairs \pm erect to antrorse, $(0.1-) 0.2-0.6 \mathrm{~mm}$ long, brown to dark brown; axillary brachyblasts present; leaves regularly arranged in the same plane, but not close together, forming flat but irregular shaped tiers (in outline). Branchlets 1.5-3 


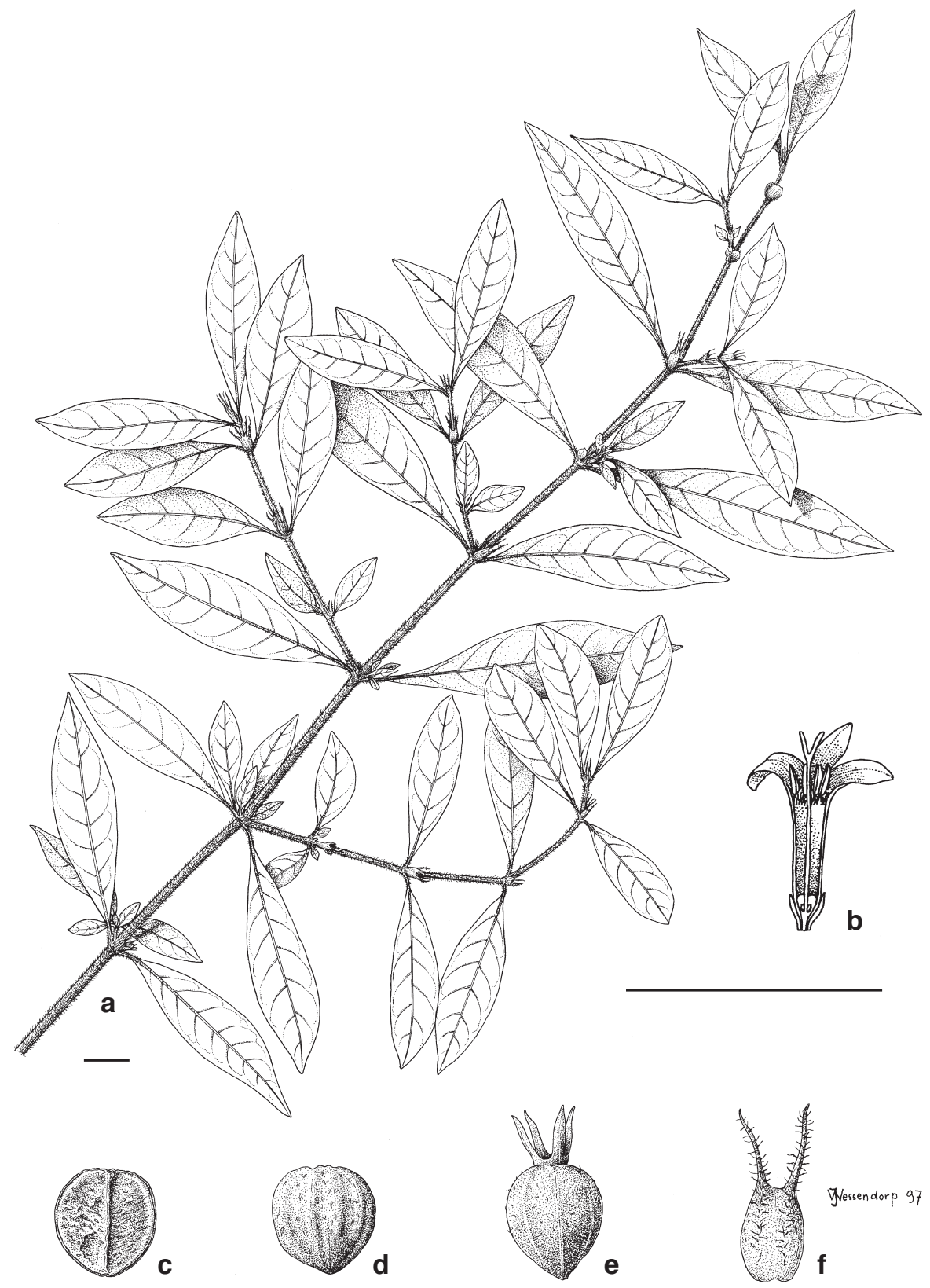

Fig. 1. Amaracarpus pubescens Blume. a. Habit; b. flower dissection; c. pyrene, ventral (adaxial) view, showing marginal preformed germination slits (PGSs); d. pyrene, dorsal (abaxial) view; e. fruit, with persistent calyx limb and lobes; f. stipule (all: Van Balgooy \& Van Setten 5665 (L)). Drawn by J. Wessendorp. - Scale bars: $\mathrm{a}=1 \mathrm{~cm} ; \mathrm{b}-\mathrm{f}=1 \mathrm{~cm}$. 
mm diam., smooth, brown, hirsutellous to pubescent. Stipules connate at the base or up to $1 / 3$ their length, oblong to depressed-ovate, $4.5-7(-9)$ by $2-3 \mathrm{~mm}$, chartaceous, hirsutellous to pubescent or glabrous, apex truncate to obtuse, with 2 prominent setae, setae (0.5-)2-4 mm long, hirsutellous to pubescent. Leaves: petioles $(0.5-) 1-3(-8)$ $\mathrm{mm}$ long, hirsutellous to pubescent; leaf blades elliptic to oblong-elliptic, broadly elliptic, or \pm narrowly ovate to narrowly ovate, infrequently narrowly elliptic to narrowly obovate or subobovate, $(0.4-) 1.8-8.5(-10)$ by $(0.4-) 1-1.9(-2.7) \mathrm{cm}$, chartaceous, usually drying grey but sometimes green, base acute to shortly attenuate, apex acute or infrequently broadly acuminate; abaxial surface: midrib hirsutellous to pubescent, rarely glabrous, secondary veins (3-)5-10 pairs, prominent or rarely indistinct, ascending at an angle of $30-45^{\circ}$, hirsutellous to pubescent, rarely glabrous, venation manifest, rarely obscure; abaxial surface glabrous or rarely scabrid; adaxial surface glabrous, although midrib sometimes hirsutellous to pubescent especially near the base. Inflorescences terminal on axillary brachyblasts (near-axillary) or axillary, rarely terminal on short side shoots or 1(-3)-flowered, sessile; bracts and bracteoles absent. Flowers sessile. Calyx (incl. hypanthium) 2-4 by 1-2 mm, glabrous or hirsutellous to puberulous, calyx lobes triangular to narrowly triangular, or linear, (1.2-) $2-2.5$ by $0.5 \mathrm{~mm}$, glabrous to puberulous. Corolla $(3-) 4-6(-8)$ by $(2-) 2.5-3 \mathrm{~mm}$, external surface glabrous, internal surface with a ring of hairs, corolla lobes $3-4$ by $1-1.5 \mathrm{~mm}$. Stamens: anthers c. $0.7 \mathrm{~mm}$ long; filaments (0.5-)0.8-1 mm long. Style (3.5-)5-7 $\mathrm{mm}$ long. Fruit (3-)5.5-8 by (2-)4-5 mm, sessile; calyx $1.5-3 \mathrm{~mm}$ long. Pyrenes (3-) $4.5-6$ by $(2.5-) 3.5-4.5 \mathrm{~mm}$.

Note - Amaracarpus pubescens has a wide distribution, extending from the Seychelles in the western part of the Indian Ocean, throughout SE Asia, to New Guinea (Papua Barat). Throughout its range it can be quite variable, particularly with respect to leaf size, leaf shape, and pubescence. The type specimen of $A$. pubescens comes from Java, and most collections are very much like the type. Material found to the east of Java, however, is much more variable. In Sulawesi, for example, there are plants with relatively small, usually obovate leaves, and these have been recognized here as A. pubescens subsp. microphyllus. Some collections from Sulawesi (e.g. Coode 5942, 5971) exhibit distinct leaf heteromorphy (aside from the much smaller leaves of the axillary brachyblasts, which are present in most Amaracarpus species): the leaves of some branches are up to three times the size of others. This size variation may be due to age, with the smaller leaves representing immature foliage. Amaracarpus pubescens subsp. sechellarum F. Friedmann (1994), from the Seychelles, falls well within the range of variation for Amaracarpus pubescens subsp. pubescens and is accordingly not recognized as a distinct entity by us.

\section{KEY TO THE SUBSPECIES}

1a. Leaf blades $>2.5 \mathrm{~cm}$ long, secondary veins $5-10$ pairs . . . a. subsp. pubescens

b. Leaf blades $<2.2 \mathrm{~cm}$, secondary veins $3-5$ pairs . . . . b. subsp. microphyllus

\section{a. subsp. pubescens}

Amaracarpus pubescens Blume subsp. sechellarum F. Friedmann (1994) 581, pl. 181. - Type: Friedmann 5259 (holo P), Seychelles, Silhouette, June 1985. 
Leaves: petioles 1-3(-8) mm long; leaf blades elliptic to oblong-elliptic, or \pm narrowly ovate to narrowly ovate, infrequently narrowly elliptic to narrowly obovate or subobovate, $(2.2-) 2.5-8.5(-10)$ by $1-1.9(-2.7) \mathrm{cm}$, secondary veins $5-10$ pairs.

Distribution - The Seychelles (Silhouette, Mahé), Myanmar, Andaman Islands (Andaman Island, Little Andaman Island), Nicobar Islands (Katchal Island); Thailand, Sumatra, Java, Borneo (Kalimantan), Bali, Sumbawa, Sumba, Flores, Timor, Sulawesi, Moluccas (Kepulauan Talaud, ?Halmahera, Kepulauan Tanimbar, Kepulauan Kai), Papua Barat (Vogelkop Peninsula), Christmas Island. Amaracarpus pubescens is believed to be extinct on Mahé (The Seychelles).

Habitat \& Ecology - On ridges, river flats and riverbanks; substrate: limestone, coralline limestone, sand, granite, and clay with gravel; locally common to scattered; altitude $0-1600(-2400) \mathrm{m}$.

b. subsp. microphyllus (Miq.) A.P. Davis, stat. nov.

Amaracarpus microphyllus Miq. (1869) 211; Elmer (1911) 1036 [as 'microphylla']. - Type: De Vriese \& Teijsmann s.n. (holo L; iso L, U), Celebes, in prov. Menado [sic.], 1859-1860.

Amaracarpus apoensis Elmer (1915) 2804. - Type: Elmer 10737 (holo PNH; iso A, L, NY, P), Philippines, Todaya (Mt Apo), District of Davao, Mindanao, May 1909.

Leaves: petioles (0.5-)1-2(-4) mm long; leaf blades elliptic to broadly elliptic, narrowly obovate or \pm obovate, $(0.4-) 0.6-2.2$ by $(0.4-) 0.8-1.2 \mathrm{~cm}$, secondary veins 3-5 pairs.

Distribution - Philippines, Sulawesi, Moluccas (Halmahera, Seram).

Habitat \& Ecology - Near rivers; substrate: clay, gravel; altitude 70-500 m.

\section{Amaracarpus kochii Valeton}

Amaracarpus kochii Valeton (1927) 116. - Type: Koch 16 (holo L; iso BO), [Papua Barat], Etnabaai, 1904-1905.

Treelet or shrub, $0.3-1.5 \mathrm{~m}$ high, glabrous, or puberulous to pubescent, rarely hirsutellous (stipules only), hairs antrorse to \pm erect, $0.1-0.2(-0.6) \mathrm{mm}$ long, brown to dark brown; axillary brachyblasts present; leaves regularly arranged in the same plane, but not close together, forming flat but irregular shaped tiers (in outline). Branchlets 1-2 mm diam., smooth, whitish to brown, \pm glabrous, or puberulous to pubescent. Stipules free or connate at the base, oblong, $3-4.5$ by $1.5-2 \mathrm{~mm}$, membranous, glabrous to hirsutellous, apex truncate, with 2 prominent setae, setae $1-2.5 \mathrm{~mm}$ long, glabrous to hirsutellous. Leaves: petioles (0.5-)2-6 mm long, glabrous to puberulous; leaf blades elliptic to narrowly elliptic, rarely subovate, rarely subobovate, (1.2-)2-9.5(-11) by (0.7-)1.1-2.7 cm, chartaceous, usually drying green, base acute to obtuse, apex acute to acuminate; abaxial surface: midrib glabrous to puberulous, secondary veins (4-)5-8(-11) pairs, prominent to obscure, ascending at an angle of $30-45^{\circ}$, glabrous to puberulous, venation manifest or obscure; abaxial surface glabrous; adaxial surface glabrous. Inflorescences terminal on axillary brachyblasts (near-axillary) to axillary, 1(-3)-flowered, sessile; bracts and bracteoles absent. Flowers sessile. Calyx (incl. hypanthium) $2-3$ by $1-2 \mathrm{~mm}$, glabrous, calyx lobes deltate to narrowly triangular, or \pm elliptic, $1-2.1$ by $0.6-1.2 \mathrm{~mm}$, glabrous. Corolla $4-6$ by $2.5-3 \mathrm{~mm}$, external surface 
glabrous, internal surface with a ring of hairs, corolla lobes $2-3$ by $1-1.5 \mathrm{~mm}$. Stamens: anthers c. $0.7 \mathrm{~mm}$ long; filaments $0.8-1 \mathrm{~mm}$ long. Style $3-5 \mathrm{~mm}$ long. Fruit $6.5-9$ by 4.5-6 mm, sessile; calyx $1-1.5 \mathrm{~mm}$ long. Pyrenes $5-6$ by $4-4.5 \mathrm{~mm}$.

Distribution - Papua Barat (incl. Vogelkop Peninsula), and Papua New Guinea.

Habitat \& Ecology - On slopes and in valleys; substrate: granites and volcaniclastic sediments; scattered; altitude 50-560 m.

Uses - Plants used to 'chase' ants and cockroaches from palm leaf roofing.

Notes - Amaracarpus kochii is morphologically very similar to A. pubescens, but can be separated by its puberulous to glabrous venation (instead of hirsutellous to pubescent, rarely glabrous, venation) and broader leaves that dry green (never grey or greyish).

Material of A. kochii from Papua New Guinea differs from the type and other material from Papua Barat by its smaller leaves and less strongly manifest venation. In the future, when more collections are available (and particularly from other parts of Papua Barat), it may be necessary to provide formal taxonomic rank for the collections from Papua New Guinea.

\section{Amaracarpus papuanus Valeton - Fig. 2}

Amaracarpus papuanus Valeton (1911) 501; (1909-1914) pl. 126. - Type: Versteeg 1591 (holo BO; iso L), Südwest Neu-Guinea [Papua Barat], Noordriver, bivak Alkmaar, $\pm 30 \mathrm{~m}$ [without date].

Shrub, c. $1 \mathrm{~m}$ high, pubescent to puberulous, hairs antrorse to \pm erect, $(0.2-) 0.3-0.4 \mathrm{~mm}$ long, light brown; axillary brachyblasts numerous; leaves close together and regularly arranged in the same plane, forming flat, regular tiers of regular shape (in outline). Branchlets 1.5-2.5 mm diam., longitudinally striated, whitish to brown, pubescent. Stipules free at base, oblong to \pm square, $2-3.5$ by $1-2 \mathrm{~mm}$, thinly chartaceous to membranous, glabrous to pubescent, apex truncate to obtuse, with 2 setae, setae $0.3-1$ $\mathrm{mm}$ long, glabrous to pubescent. Leaves: petioles (0.1-) $0.5-1 \mathrm{~mm}$ long, pubescent; leaf blades \pm elliptic to broadly elliptic, or subobovate to obovate, $(0.7-) 0.9-2.6(-3.1)$ by $(0.3-) 0.4-1.1 \mathrm{~cm}$, chartaceous, drying green or greyish, base acute to shortly attenuate or obtuse, apex acute to abruptly acuminate; abaxial surface: midrib glabrous to puberulous, secondary veins $3-5(-6)$ pairs, manifest to prominent, ascending at an angle of c. $45^{\circ}$, glabrous or puberulous, venation manifest to \pm invisible; abaxial surface glabrous; adaxial surface glabrous. Inflorescences terminal on axillary brachyblasts (near-axillary) to axillary, 1-flowered, sessile; bracts and bracteoles absent. Flowers sessile. Calyx (incl. hypanthium) (1-)2.5-3 by (1-)2-2.5 mm, glabrous, calyx lobes deltate to triangular, $(0.7-) 1.5-2$ by $(0.5-) 1 \mathrm{~mm}$, glabrous. Corolla $(0.7-) 3$ by $2-3.5(-4.4) \mathrm{mm}$, external surface glabrous, internal surface with a ring of hairs, corolla lobes c. 2.5 by $1-1.5 \mathrm{~mm}$. Stamens: anthers c. $0.5 \mathrm{~mm}$ long; filaments $0.5-0.7$ $\mathrm{mm}$ long. Style $2-3 \mathrm{~mm}$ long. Fruit $3.5-4.5$ by $3.5-4 \mathrm{~mm}$, sessile; calyx c. $1 \mathrm{~mm}$ long. Pyrenes c. 4 by $3 \mathrm{~mm}$.

Distribution - Papua Barat, Papua New Guinea, Arau Island.

Habitat \& Ecology - Recorded with Castanopsis spp. and Quercus spp.; altitude (50-)300-1400 m. 

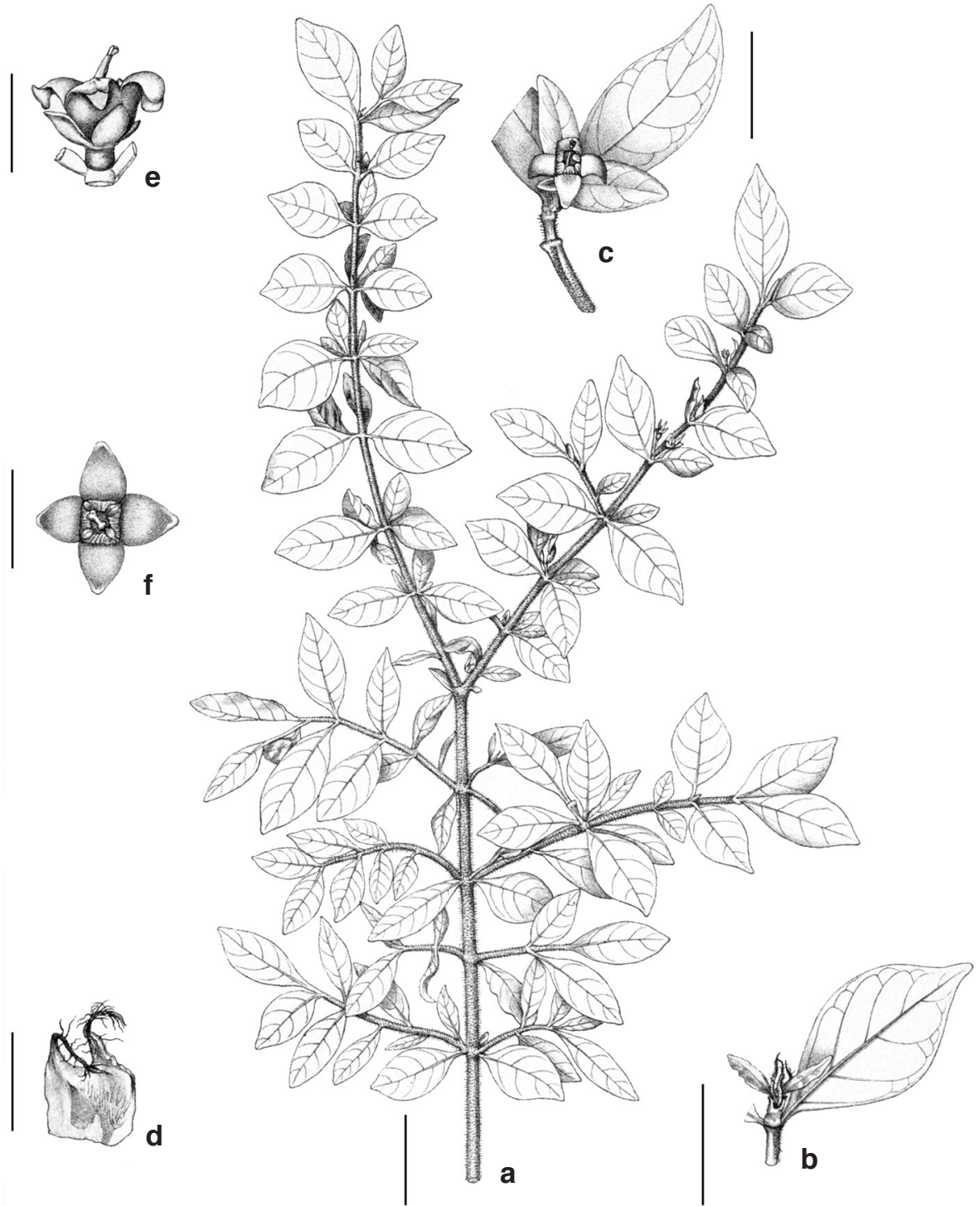

Fig. 2. Amaracarpus papuanus Valeton. a. Habit (flowering specimen); b. detail of shoot apex, including young leaves and stipule (one leaf blade removed); c. detail of axillary side shoots (axillary brachyblasts), showing reduced leaves and a single flower; d. stipule, with two setae; e. flower (side view), with petioles of reduced leaves at base (leaf blades removed); f. flower, view from above, showing 4-merous flower parts and ring of corolla throat hairs. Drawn by R. Natadipoera; reproduced from Nova Guinea 8, 3 (1909-1914) pl. 126 (modified for publication here). - Scale bars: a $=2$ $\mathrm{cm} ; \mathrm{b}=1 \mathrm{~cm} ; \mathrm{c}=5 \mathrm{~mm} ; \mathrm{d}=2 \mathrm{~mm} ; \mathrm{e}, \mathrm{f}=3 \mathrm{~mm}$. 


\section{Amaracarpus schlechteri Valeton}

Amaracarpus schlechteri Valeton (1927) 116. - Type: Schlechter 16550 (holo B †; iso A, K, L), [Papua New Guinea], Bolobo, 1000 m, 9 Nov. 1907.

Amaracarpus atrocarpus Merr. \& L.M. Perry (1946) 225. - Type: Brass 6741 (holo A; iso BM, K,

L), Papua New Guinea, Fly River, 528 mile Camp, 80 m, May 1936.

Treelet or shrub, 2-3 m high, glabrous, or puberulous to pubescent, hairs antrorse 0.1-0.2 mm long, light brown to brown; axillary brachyblasts few to absent; leaves close together and regularly arranged in the same plane, forming flat, regular tiers of regular shape (in outline). Branchlets 1-2 mm diam., \pm smooth, dark brown, puberulous to pubescent. Stipules free or connate at the base, \pm oblong, (2-) $3-4.5$ by $1.5 \mathrm{~mm}$, 2 -veined, membranous, glabrous to puberulous, apex truncate to obtuse or infrequently acute, with 2 setae, setae $2-3 \mathrm{~mm}$ long, puberulous. Leaves: petioles (0-) 0.1-0.5 mm long, glabrous to puberulous; leaf blades broadly elliptic to elliptic-rhombic, ovate or obovate, $1.3-2.3$ by $0.5-1.1 \mathrm{~cm}$, sometimes slightly asymmetrical, chartaceous, usually drying green, base cuneate to rounded, apex acute, or abruptly acuminate; abaxial surface: midrib glabrous to puberulous, secondary veins $(4-) 5-6(-8)$ pairs, manifest, ascending at an angle of $30-45^{\circ}$, glabrous, venation obscure; abaxial surface glabrous; adaxial surface glabrous. Inflorescences terminal at the apex of axillary brachyblasts (near-axillary) to axillary, 1-flowered, \pm sessile; bracts and bracteoles absent. Flowers sessile. Calyx (incl. hypanthium) $2-4$ by $1-2.5 \mathrm{~mm}$, glabrous, calyx lobes deltate to triangular, $1-1.5$ by $0.7-1 \mathrm{~mm}$, glabrous. Corolla $4-4.5$ by $2.5-3.5 \mathrm{~mm}$, external surface glabrous, internal surface with a ring of hairs, corolla lobes $1.5-3$ by $0.5-1.5$ mm. Stamens: anthers c. $1 \mathrm{~mm}$ long; filaments c. $0.3 \mathrm{~mm}$ long. Style c. $6 \mathrm{~mm}$ long. Fruit $4.5-6$ by $3-3.5 \mathrm{~mm}$, sessile; calyx (1-)3-3.5 mm long. Pyrenes c. 4 by $3 \mathrm{~mm}$.

Distribution - Papua Barat and Papua New Guinea.

Habitat \& Ecology - Near streams; locally very common; altitude 80-1000 m.

\section{Amaracarpus calcicola Merr. \& L.M. Perry}

Amaracarpus calcicola Merr. \& L.M. Perry (1946) 224. - Type: Brass 8849 (holo A; iso BM, L), Irian Jaya [Papua Barat], Tabati, Jautefa Bay, 17 June 1938.

Shrub, 1-2(-3) $\mathrm{m}$ high, glabrous to pubescent, hairs antrorse to \pm erect, $(0.1-) 0.2-0.3$ $\mathrm{mm}$ long, light brown; axillary brachyblasts present; leaves rather irregularly arranged, forming \pm flat, \pm irregular tiers of irregular shape (in outline). Branchlets $1.5-2.5 \mathrm{~mm}$ diam., often longitudinally striated, often soft and slightly spongy, whitish to dark brown, glabrous to pubescent. Stipules free at the base, \pm oblong, $3.5-6$ by $1-1.5 \mathrm{~mm}$, chartaceous to membranous, glabrous or pubescent, apex truncate to obtuse, with 2 setae, setae (0.7-)1.5-2 mm long, glabrous to pubescent. Leaves: petioles $0.5-1.5(-3) \mathrm{mm}$ long, glabrous; leaf blades elliptic-obovate, obovate to narrowly obovate, or almost spathulate, $(0.8-) 1.2-2(-2.7)$ by $0.4-0.7(-0.9) \mathrm{cm}$, chartaceous to subcoriaceous, usually drying grey, base attenuate, apex obtuse to broadly acute; abaxial surface: midrib glabrous, secondary veins 3-4(-6) pairs, obscure to invisible, ascending at an angle of c. $60^{\circ}$, basal vein elongated, glabrous, venation invisible; abaxial surface glabrous; adaxial surface glabrous. Inflorescences terminal on axillary brachyblasts (near-axillary), 1-flowered, sessile; bracts and bracteoles absent. Flowers sessile. Calyx 
(incl. hypanthium) $2.5-3$ by $1-2 \mathrm{~mm}$, glabrous, calyx lobes triangular, $1-1.5$ by $0.3-0.5$ $\mathrm{mm}$, glabrous to puberulous. Corolla $4-5$ by $2-3 \mathrm{~mm}$, external surface glabrous, internal surface with a ring of hairs, corolla lobes $2-3$ by $1-1.5 \mathrm{~mm}$. Stamens: anthers $0.5-0.7 \mathrm{~mm}$ long; filaments $0.5-1 \mathrm{~mm}$ long. Style c. $2.5 \mathrm{~mm}$ long. Fruit $2.5-5.5$ by 2.5-4 mm, sessile; calyx $0.5-1 \mathrm{~mm}$ long. Pyrenes $2.5-4.5$ by $2-3 \mathrm{~mm}$.

Distribution - N Papua Barat and Papua New Guinea.

Habitat \& Ecology - Sometimes on riverbanks amongst rocks; recorded with Casuarina spp., Quercus spp., Podocarpus spp., Intsia spp., and Pometia spp.; substrate: limestone; altitude 100-200 m.

Note - Amaracarpus calcicola is most likely to be confused with A. nymanii. These species are easily separated from each other on the basis of stipule morphology: A.calcicola has two setae at the apex of the stipule, whereas the stipule apex of $A$. nymanii is acute or has one seta.

\section{Amaracarpus cuneifolius Valeton - Fig. 3}

Amaracarpus cuneifolius Valeton (1911) 502; (1909-1914) pl. 127. - Type: Versteeg 1680 (lectotype BO, selected here; isolectotypes K, L, U), Nova Guinea neerlandica meridionalis/SüdwestNeu Guinea [Papua Barat], in mont Resi, 350 m [without date].

Shrub, 1-2 m high, puberulous to sparsely pubescent, hairs antrorse to erecto-patent, 0.1-0.2 mm long, brown to dark brown; axillary brachyblasts few or absent; leaves close together and regularly arranged in the same plane, forming flat, regular tiers of irregular to \pm regular shape (in outline). Branchlets 1-2 mm diam., \pm smooth, brown to dark brown, sparsely pubescent but hairs rather obvious. Stipules slightly sheathing to \pm free at the base, \pm oblong to triangular, $1.7-3$ by 1-1.5 mm, 2-veined, membranous, glabrous or puberulous, apex truncate to obtuse, with 2 setae, setae $0.7-1 \mathrm{~mm}$ long, puberulous. Leaves: petioles (0-)0.1-0.5(-1) mm long, glabrous to puberulous; leaf blades narrowly obovate-rhombic to rhombic, elliptic, or rarely ovate to deltate, $0.7-1.1$ by $0.4-0.5 \mathrm{~cm}$, chartaceous, usually drying green, base acute, apex abruptly acuminate, rarely acute; abaxial surface: midrib glabrous to puberulous, secondary veins 3 or 4 pairs, manifest, ascending at an angle of c. $45^{\circ}$, glabrous to puberulous, venation manifest to obscure; abaxial surface glabrous; adaxial surface glabrous. Inflorescences terminal on axillary brachyblasts (near-axillary), or on short side shoots, or axillary, 1- (or 2-)flowered, \pm sessile; bracts and bracteoles absent. Flowers sessile to very shortly pedicellate, pedicel (if present) $0.1-0.4 \mathrm{~mm}$ long. Calyx (incl. hypanthium) $2-3$ by $2 \mathrm{~mm}$, glabrous, calyx lobes \pm deltate, $0.5-1$ by $0.5-1.5 \mathrm{~mm}$, glabrous. Corolla $2.2-5(-6)$ by $3-4.5 \mathrm{~mm}$, external and internal surfaces glabrous, corolla lobes $1-2$ by $1 \mathrm{~mm}$. Stamens: anthers c. $0.3 \mathrm{~mm}$ long; filaments c. $0.3 \mathrm{~mm}$ long. Style $2.5-3 \mathrm{~mm}$ long. Fruit $5-6$ by $3.5 \mathrm{~mm}$, pedicel $0.1-0.5 \mathrm{~mm}$ long; calyx $0.2-0.5 \mathrm{~mm}$ long. Pyrenes c. 4.2 by $3.1 \mathrm{~mm}$.

Distribution - Papua Barat and Papua New Guinea.

Habitat \& Ecology - Riversides, ridges; substrate: granites and volcaniclastic sediments; altitude 400-1700 m.

Note - We have selected the specimen Versteeg 1680 as the lectotype for this species. The specimen Wichmann 6, the second specimen cited by Valeton (1911: 502) in the protologue of A.cuneifolius, represents A. wichmannii (see Gibbs, 1917: 221). 


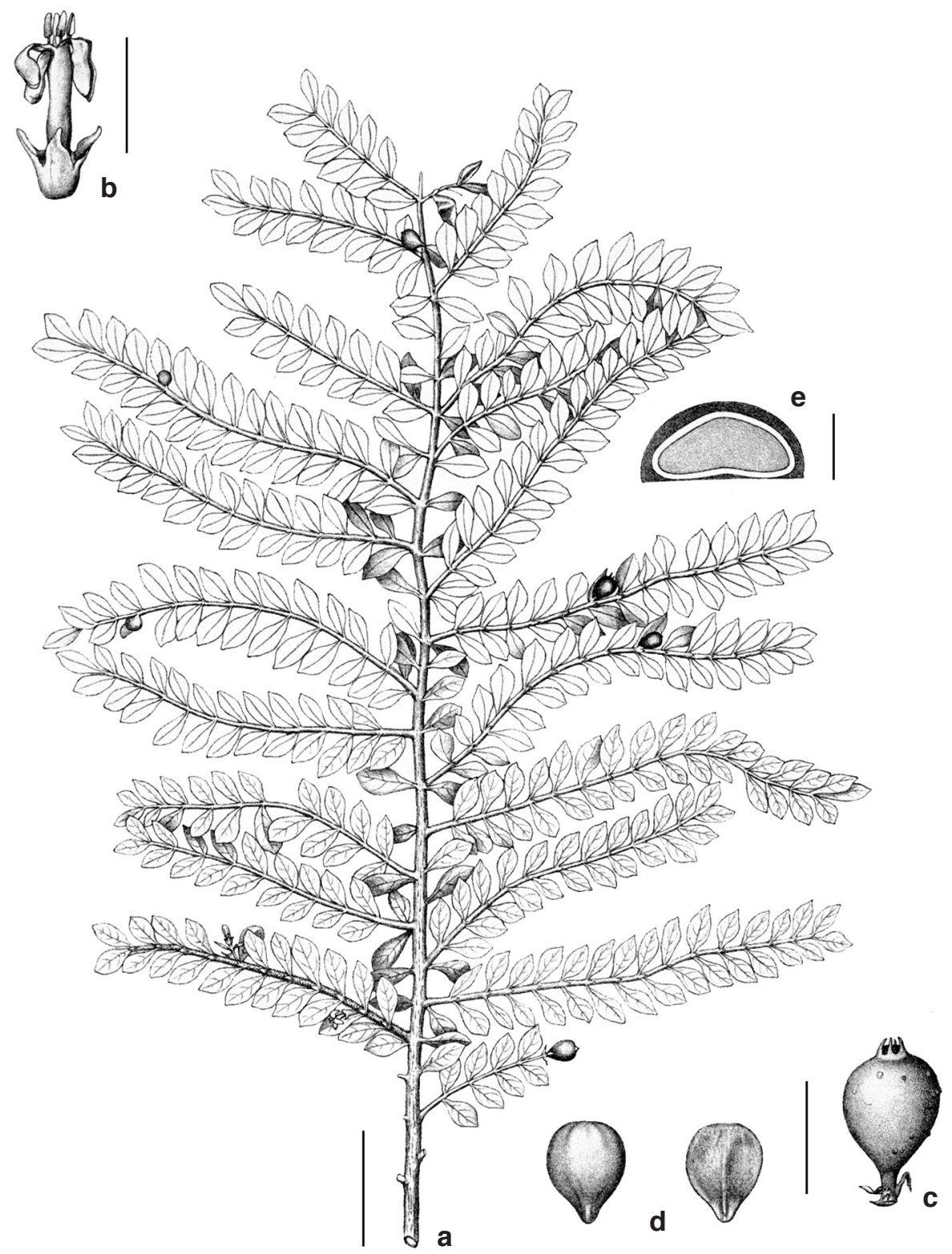

Fig. 3. Amaracarpus cuneifolius Valeton. a. Habit (fruiting specimen); b. flower; c. fruit; d. pyrene, dorsal (abaxial) and ventral (adaxial) views (left to right); e. transverse section through (part of) fruit, showing smooth dorsal surface of pyrene. Drawn by R. Natadipoera; reproduced from Nova Guinea 8, 3 (1909-1914) pl. 127 (modified for publication here). - Scale bars: a = 2 cm; b, c, d = $5 \mathrm{~mm}$; $=1.7 \mathrm{~mm}$. 
7. Amaracarpus grandiflorus A.P. Davis, spec. nov.

A. belensi Merr. \& L.M. Perry affinis sed stipulis ad apicem acutis (nec apiculo 2-setulosis) et corolla $8.5-17 \mathrm{~mm}$ longa (nec 3 by 2-2.5 mm longa), differt. - Typus: Eyma 2368 (holo L; iso B, K), Seram, tanah goedoer-Hoàlepas, 40 m, 1 Dec. 1937.

Tree or shrub, 2-4(-6) $\mathrm{m}$ high, puberulous to pubescent, hairs antrorse to erect, $0.1-0.2$ $\mathrm{mm}$ long, brown to dark brown; axillary brachyblasts few or absent; leaves rather irregularly to \pm regularly arranged, forming \pm flat, \pm regular tiers of irregular shape (in outline). Branchlets 1-2.5 mm diam., \pm smooth, brown, puberulous to pubescent. Stipules connate at the base and sometimes for more than $1 / 2$ their length, or mostly free, triangular to narrowly triangular, or \pm narrowly ovate, $1.3-2.7$ by $0.8-1.5 \mathrm{~mm}$, subcoriaceous to chartaceous, glabrous, apex acute to narrowly acute. Leaves: petioles 0.5-1.2(-3.5) mm long, glabrous; leaf blades elliptic-rhombic, or rhombic-narrowly obovate to rhombic-obovate, or obovate to narrowly obovate, $0.4-1.3(-2.2)$ by $(0.2-) 0.3-0.6(-1) \mathrm{cm}$, chartaceous, usually drying green, base attenuate to decurrent, apex broadly acute to obtuse; abaxial surface: midrib glabrous, secondary veins 3 or 4 (or 5 ) pairs, obscure to manifest, ascending at an angle of $30-45^{\circ}$, glabrous, venation invisible; abaxial surface glabrous; adaxial surface glabrous. Inflorescences terminal at the apex of side shoots and/or the axillary brachyblasts (near-axillary), 1-flowered, sessile; bracts and bracteoles absent. Flowers sessile or pedicellate; pedicel (if present) $0.2-0.5 \mathrm{~mm}$ long. Calyx (incl. hypanthium) $1.6-2.7$ by $1.8-3 \mathrm{~mm}$, glabrous, calyx lobes \pm deltate to narrowly triangular, $0.7-1.4$ by $0.5-0.7 \mathrm{~mm}$, glabrous. Corolla $(8.5-) 9-17$ by (3.8-) 6-8.7 mm, external surface and internal surfaces glabrous, corolla lobes $2.5-5$ by (1.2-)1.7-2.3 mm. Stamens: anthers c. $3 \mathrm{~mm}$ long; filaments c. $0.2 \mathrm{~mm}$ long. Style (9-) 10-14 mm long. Fruit $6.5-8$ by $3.2-5 \mathrm{~mm}$, pedicel $0.2-0.5 \mathrm{~mm}$ long, or sessile; calyx $0.7-1.5 \mathrm{~mm}$ long. Pyrenes $5.5-6.1$ by $3.6-4.4 \mathrm{~mm}$.

Distribution - Moluccas (Seram). At the present time this species has only been recorded from Seram, and it is possibly restricted to altitudes above c. $1200 \mathrm{~m}$ in the Manusela National Park.

Habitat \& Ecology - On slopes; recorded with trees 15-20 m high; substrate: limestone; altitude (?40-)1200-2200 m.

Note - This species was first collected in 1937 (Eyma 2368) but was overlooked until more recent multiple collections were made by staff of the University of Tokyo and Herbarium Bogoriense in 1984-1985. As the name suggests A. grandiflorus has large flowers, which are in fact the largest of any Amaracarpus species. It is similar to A. belensis, also from Seram, but differs owing to its acute stipule and much larger flowers (see diagnosis). Amaracarpus pubescens subsp. microphyllus also occurs in Seram, but this has larger leaves and stipules with 2 setae. Amaracarpus grandiflorus is endemic to Seram and is mainly restricted to altitudes above $1200 \mathrm{~m}$.

\section{Amaracarpus belensis Merr. \& L.M. Perry}

Amaracarpus belensis Merr. \& L.M. Perry (1946) 228. - Type: Brass 11055 (holo A; iso BM, L), Irian Jaya [Papua Barat], Bele River, 18 km NE of Lake Habbema, 2300 m, Nov. 1938. [Amaracarpus minutifolius Valeton in schedae.]

Treelet or shrub, 3-4 m high, puberulous to pubescent, hairs antrorse to \pm erect, $0.1-0.2$ $\mathrm{mm}$ long, brown to dark brown; axillary brachyblasts few to quite prominent; leaves 
close together and regularly arranged in the same plane, forming flat, \pm regular tiers of irregular to regular shape (in outline). Branchlets $0.5-1 \mathrm{~mm}$ diam., \pm smooth, dark brown, puberulous to pubescent. Stipules free or connate at the base, broadly obovate to \pm square or oblong, $(0.5-) 1-2$ by $1(-2) \mathrm{mm}$, membranous to almost subcoriaceous, puberulous to glabrous, apex truncate to broadly cuneate, with 2 setae, setae $0.2-0.5$ $\mathrm{mm}$ long, glabrous to puberulous. Leaves: petioles $0.7-3.5 \mathrm{~mm}$ long, \pm glabrous to puberulous; leaf blades elliptic to elliptic-rhombic, or rhombic-narrowly obovate, rarely obovate, $(0.3-) 0.4-0.9(-1.2)$ by $(0.2-) 0.3-0.4(-0.6) \mathrm{cm}$, chartaceous to subcoriaceous, base acute, apex acute to abruptly acuminate; abaxial surface: midrib glabrous to puberulous, secondary veins 3 or 4 pairs, obscure to invisible, ascending at an angle of c. $45^{\circ}$, glabrous, venation obscure to invisible; abaxial surface glabrous; adaxial surface glabrous. Inflorescences terminal at the apex of side shoots and/or terminal on axillary brachyblasts (near-axillary), 1-flowered, sessile; bracts and bracteoles absent. Flowers sessile. Calyx (incl. hypanthium) $2-2.5$ by $1.5-2.5 \mathrm{~mm}$, glabrous, calyx lobes \pm deltate, $0.4-0.6$ by $0.2 \mathrm{~mm}$, margins puberulous to glabrous. Corolla c. 3 by $2-2.5$ $\mathrm{mm}$, external and internal surfaces glabrous, corolla lobes c. $0.5 \mathrm{~mm}$ long. Stamens: anthers $0.2-0.3 \mathrm{~mm}$ long; filaments $0.3-0.5 \mathrm{~mm}$ long. Style $1-2 \mathrm{~mm}$ long. Fruit $4-5$ by $2.5-3 \mathrm{~mm}$, sessile; calyx c. $1.5 \mathrm{~mm}$ long. Pyrenes 4 by $2.5-3 \mathrm{~mm}$.

Distribution - Moluccas (Seram), Papua Barat and Papua New Guinea.

Habitat \& Ecology — Substrate: limestone; locally common; altitude (480-)1210 $2300 \mathrm{~m}$.

Uses - Leaves said to promote hair growth if rubbed into scalp.

Note - Specimens of $A$. belensis from Seram have been provisionally placed with this species, although they differ slightly from the type. Differences include slightly longer calyx teeth, a slightly longer corolla and leaves more or less consistently chartaceous. Further collecting may reveal that collections from Seram need to be given taxonomic status.

\section{Amaracarpus anomalus Wernham}

Amaracarpus anomalus Wernham (1916) 78. - Type: Boden Kloss s.n. (holo BM), [Papua Barat], Utakwa River to Mt Carstenz, Camp ix-x, 5500-6700 ft [1676-2042 m], 26 Jan. 1913.

Shrub, height unknown, puberulous to pubescent, hairs erect to erecto-patent, (0.1-) 0.2-0.3 mm long, brown to dark brown; axillary brachyblasts present, few; leaves rather irregularly arranged, forming flat, \pm irregular tiers of irregular shape (in outline). Branchlets 1-1.5 mm diam., smooth, light to dark brown, puberulous to pubescent. Stipules connate at the base or free, deltate to square, $1-2.5$ by $0.7-2.5 \mathrm{~mm}, 2$-veined, membranous, glabrous to puberulous, apex truncate or obtuse, with 2 setae, setae $0.3-0.5$ $\mathrm{mm}$ long, puberulous. Leaves: petioles $(0-) 0.5-1 \mathrm{~mm}$ long, glabrous to pubescent; leaf blades obovate to elliptic-rhombic, $0.6-1.1$ by $0.3-0.7 \mathrm{~cm}$, chartaceous, usually drying dark green, base narrowly cuneate, apex rounded to abruptly acuminate; abaxial surface: midrib glabrous to minutely puberulous, secondary veins 3 or 4 pairs, manifest to obscure, ascending at an angle of c. $45^{\circ}$, glabrous, venation obscure to \pm invisible; abaxial surface glabrous; adaxial surface glabrous. Inflorescences terminal at the apex of side shoots, 1-flowered, sessile; bracts and bracteoles absent. Flowers sessile. Calyx (incl. hypanthium) $1.5-2$ by $1.5 \mathrm{~mm}$, glabrous, calyx lobes \pm deltate, $0.5-1$ by $0.2-0.3$ 
$\mathrm{mm}$, margins puberulous. Corolla $2-4.5$ by $1.5-3 \mathrm{~mm}$, external surfaces puberulous or glabrous, internal surface with a ring of hairs, corolla lobes $2-3$ by $1 \mathrm{~mm}$. Stamens: anthers c. $0.7 \mathrm{~mm}$ long; filaments c. $0.3 \mathrm{~mm}$ long. Style $4-5 \mathrm{~mm}$ long. Fruit c. 3 by $1.5 \mathrm{~mm}$ (immature), sessile; calyx c. $1 \mathrm{~mm}$ long. Pyrenes not seen.

Distribution - Papua Barat. Only known from two locations in SW Papua Barat: Mt Carstensz [Mt Jaya] and Wissel Lake [Lake Paniai] region.

Habitat \& Ecology — Poorly known. Riversides.

\section{Amaracarpus brassii Merr. \& L.M. Perry}

Amaracarpus brassii Merr. \& L.M. Perry (1946) 229. - Type: Brass 10823 (holo A; iso L), Papua Barat, 9 km NE of Lake Habbema, 2700 m, Oct. 1938.

Treelet or shrub, 3-4 m high, puberulous to pubescent, or \pm glabrous, hairs antrorse to \pm erect, $0.1-0.2 \mathrm{~mm}$ long, brown to dark brown; axillary brachyblasts absent; leaves rather irregularly arranged, forming flat, \pm irregular tiers of irregular shape (in outline). Branchlets 0.5-1.5 mm diam., \pm smooth, dark brown, puberulous to pubescent, or glabrous. Stipules connate at the base, \pm obovate, $0.8-1$ by $1 \mathrm{~mm}$, membranous, glabrous, apex truncate, with 2 setae, setae $0.2 \mathrm{~mm}$ long, glabrous to puberulous. Leaves: petioles c. $0.5 \mathrm{~mm}$ long, glabrous to puberulous; leaf blades cordate to deltate, or almost reniform, $0.1-0.2$ by $0.1-0.2(-0.3) \mathrm{cm}$, subcoriaceous to coriaceous; drying dark green to blackish, base cordate, or rounded to truncate, apex obtuse to broadly cuneate; abaxial surface: midrib glabrous, secondary veins invisible, glabrous, venation invisible; abaxial surface glabrous; adaxial surface glabrous. Inflorescences terminal at the apex of side shoots, 1-flowered, sessile; bracts and bracteoles absent. Flowers 4- (or 5-)merous, sessile. Calyx (incl. hypanthium) 1-1.5 by 1-1.5 mm, glabrous, calyx lobes tooth-like to deltate, $0.5-0.8$ by $0.5-0.7 \mathrm{~mm}$, margins puberulous. Corolla $2-2.5$ by $1.5 \mathrm{~mm}$, external and internal surface glabrous, corolla lobes c. 0.5 by $1 \mathrm{~mm}$. Stamens: anthers c. $0.4 \mathrm{~mm}$ long; filaments c. $0.2 \mathrm{~mm}$ long. Style c. $0.5 \mathrm{~mm}$ long. Fruit $4.5-5$ by $2.5-3 \mathrm{~mm}$, sessile; calyx c. $0.5 \mathrm{~mm}$ long. Pyrenes $2.5-3.5$ by $2-3 \mathrm{~mm}$.

Distribution - Papua Barat. Restricted to central Papua Barat, and only known from two localities: north of Lake Habbema, and Mt Trikora.

Habitat \& Ecology - Valley bottoms; occasional; altitude c. 2700 m.

Note - Amaracarpus brassii is easily recognized by its very small (1-2 mm long), cordate to deltate or almost reniform leaves. The species is currently only known from two specimens, the type and Mangen 299 (L, LUX).

\section{Amaracarpus grandifolius Valeton}

Amaracarpus grandifolius Valeton (1927) 120. - Type: Schlechter 16702 (lectotype L, selected here; isolectotypes A, K), Nordöstl. Neu-Guinea [Papua New Guinea], Kaiser-Wilhelmsland, 'in den Wäldern am Kaulo', c. 180 m, 20 Oct. 1907.

Amaracarpus grandicalyx Valeton (1927) 122. - Type: Lauterbach 1207 (lectotype WRSL, selected here), Nordöstl. Neu-Guinea [Papua New Guinea], Constantin-Hafen, Dec. 1890.

Amaracarpus brachypus Merr. \& L.M. Perry (1946) 223. - Type: Brass 3876 (holo A; iso NY), Papua New Guinea, Dieni, Ononge Road, 500 m, April-May 1933.

Amaracarpus solomonensis Merr. \& L.M. Perry (1946) 223. - Type: Brass 2955 (holo A; iso L), Solomon Islands, Ulawa [Island], 200-300 m, Oct. 1932.

[Coffea uniflora sensu K. Schum. \& Lauterb., pro parte (Lauterbach 2188, 2893), non K. Schum.] 
Tree or shrub, (0.3-)1-3.6(-7) $\mathrm{m}$ high, glabrous to subhirsute, rarely hirsute, hairs \pm erect to antrorse, $(0.1-) 0.2-1.2(-2.2) \mathrm{mm}$ long, brown; axillary brachyblasts present to numerous; leaves regularly arranged in the same plane, widely spaced or close together, forming flat, \pm regular or irregular tiers, regular or irregular shape (in outline). Branchlets 1.5-3.5 mm diam., roughish, whitish to brown, glabrous to subhirsute, rarely hirsute. Stipules connate at the base to c. $1 / 2$ their length, oblong to \pm square, narrowly ovate to narrowly elliptic, or \pm triangular, $(2-) 2.6-13(-15)$ by $0.8-4 \mathrm{~mm}$, often 2 -veined, chartaceous, glabrous to subhirsute, apex acute to narrowly acute. Leaves: petioles 0.5-6(-8) $\mathrm{mm}$ long, glabrous to hirsutellous; leaf blades \pm elliptic to narrowly elliptic, \pm narrowly ovate to narrowly ovate, rarely narrowly obovate, sometimes slightly rhombic, (0.8-)2.9-13(-15) by (0.2-)0.9-3.1(-3.8) cm, chartaceous, drying green, dark green or greyish, base acute, sometimes slightly decurrent, apex acute to subcaudate, cauda up to $0.9 \mathrm{~cm}$ long; abaxial surface: midrib glabrous to pubescent, rarely hirsutellous, secondary veins (4-)6-16(-18) pairs, prominent to obscure, ascending at an angle of c. $45^{\circ}$, glabrous to pubescent, venation usually prominent; abaxial surface glabrous to sparsely pubescent; adaxial surface glabrous. Inflorescences terminal at the apex of side shoots, or terminal on axillary brachyblasts (near-axillary) or axillary, 1-2(-5)flowered, \pm sessile; bracts and bracteoles absent. Flowers sessile to very shortly pedicellate; pedicel (if present) $0.5-1.5 \mathrm{~mm}$ long. Calyx (incl. hypanthium) 2-4 by $2-2.5 \mathrm{~mm}$, glabrous to pubescent, calyx lobes deltate to triangular, $0.2-0.5$ by $1 \mathrm{~mm}$, glabrous to pubescent. Corolla $3.5-5$ by $2-2.5 \mathrm{~mm}$, external surface glabrous, internal surface with a ring or hairs, corolla lobes $1.5-2$ by $1-2.5 \mathrm{~mm}$. Stamens: anthers $0.7-1$ $\mathrm{mm}$ long; filaments c. $0.5 \mathrm{~mm}$ long. Style $2-3 \mathrm{~mm}$ long. Fruit $4.5-6.5$ by $3.5-5 \mathrm{~mm}$, pedicel $0.5-1.7 \mathrm{~mm}$ long; calyx $1.5-3.5(-4.5) \mathrm{mm}$ long. Pyrenes $4-6$ by $4-5 \mathrm{~mm}$.

Notes - In this account A. brachypus, A. grandicalyx, A. humilis, A. lauterbachii, A. leucocarpus, A. solomonensis, and A.trichocarpus, are considered to represent synonyms of A. grandifolius. Quantitative differences (e.g. leaf size and shape) and slight differences in leaf venation patterns seem to be the only tenable criteria for recognizing distinct entities. The extensive range of variation in these characters argues against the recognition of several species. In this revision A. grandifolius is treated as a highly polymorphic species, with four rather poorly differentiated varieties (var. grandifolius, var. humilis, var. leucocarpus, and var. trichocarpus). There is both morphological and geographical overlap between varieties and each may have originated independently a number of times throughout the distribution range of the species. The remarkable variation within A. grandifolius is exemplified by the collection Sands 798 (K): sheet I is typical A. grandifolius var. grandifolius, whereas sheet II is intermediate between var. grandifolius and var. humilis.

Valeton (1927: 120, 157) deduced that Schumann \& Lauterbach (1901: 569) had cited a number of specimens of $A$. grandifolius under the name Coffea uniflora K. Schum. On the basis of the description and on inspection of two of these specimens (Lauterbach 2188 and 2893), Valeton (1927: 157) transferred C. uniflora to Ixora, making the combination I. uniflora (K. Schum.) Valeton, although he had clearly not seen the holotype ('Hollrung 607 non vidi'). It is almost certain that the holotype was destroyed in Berlin. On the basis of the description we concur with Valeton that C. uniflora is indeed an Ixora. 
Of the specimens cited by Valeton (1927) for A. grandifolius (Lauterbach 268, 1148, 2064,2215, 2432; Schlechter 14153, 16186, 16617, 16702, 17704), only the specimens Lauterbach 1148 and Schlechter 14153,16186, 16702 are known to be extant. We have selected Schlechter 16702 as the lectotype for this species.

\section{KEY TO THE VARIETIES}

1a. Leaf blades usually $>4 \mathrm{~cm}$ long $\ldots \ldots \ldots \ldots \ldots \ldots$ a. var. grandiflorus

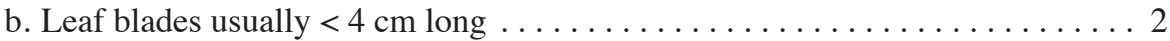

2a. Branchlets pubescent to subhirsute, rarely hirsute, hairs usually $>0.4 \mathrm{~mm}$ long . d. var. trichocarpus

b. Branchlets glabrous, or puberulous to pubescent, hairs (if present) usually $<0.3$

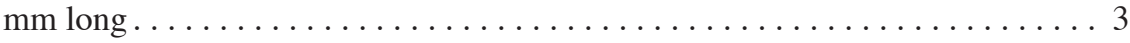

3a. Leaf blades elliptic to narrowly elliptic, narrowly ovate to narrowly obovate, drying green to dark green, or sometimes grey. . . . . . . . . . var. humilis

b. Leaf blades elliptic to narrowly obovate, leaves usually drying grey . . . . . . . .

c. var. leucocarpus

\section{a. var. grandifolius}

Tree or shrub, $(0.5-) 1.2-3.6(-7) \mathrm{m}$ high, glabrous to subhirsute, hairs \pm erect to antrorse, (0.1-)0.2-1.2 mm long, brown. Stipule: apex acute to narrowly acute. Leaves: petioles (1-)2-4(-6) mm long, glabrous to hirsutellous; leaf blades \pm elliptic to narrowly elliptic, or \pm narrowly ovate to narrowly ovate, $(2.7-) 4-13(-15)$ by (1-)2-3.1(-3.8) cm, drying green to dark green, or sometimes grey; abaxial surface glabrous to sparsely pubescent.

Distribution - Moluccas (Halmahera: Morotai), Papua New Guinea (incl. New Ireland, Kawa Island, Kiriwina Island, Goodenough Island, Fergusson Island, Bougainville Island), Solomon Islands (incl. Mbava (Baga) Island, Kolombangara Island, Malaita Island, Ulawa Island).

Habitat \& Ecology - Often on stream banks and river flats, ridge tops, and steep ridges; recorded with Albizia spp., Anisoptera spp., Castanopsis spp., Dysoxylum spp., Litsea spp., Podocarpus spp., Quercus spp., and Syzygium spp.; substrate: limestone, clay, and probably on other substrates; often locally common; 5-1100(-1320) $\mathrm{m}$ altitude.

Uses - Used for yam magic: leaves and bark boiled and eaten after pancelling [sic: definition not found] (Saki \& Wawikiak 4663; Papua New Guinea). Bark macerated and given as a drink to infants suffering from constipation (Kajewski 2394; Solomon Islands).

Note - See above under A. grandifolius.

b. var. humilis (Valeton) A.P. Davis, stat. nov.

Amaracarpus humilis Valeton (1927) 125. - Type: Schlechter 17368 (holo B†; iso A, BM, K, L), Nordöstl. Neu-Guinea [Papua New Guinea], Kaiser-Wilhelmsland, 'in den Wälderen auf dem Rani', 1000 m, 26 Feb. 1908. 
Treelet or shrub, $(0.3-) 0.5-2.5(-3) \mathrm{m}$ high, puberulous to pubescent, sometimes glabrous, hairs antrorse, (0.1-)0.2-0.3(-0.4) mm long, light brown to brown. Stipule: apex acute. Leaves: petioles (0.5-)1-2(-8) mm long, puberulous to pubescent; leaf blades elliptic to narrowly elliptic, \pm narrowly ovate to narrowly obovate, $(0.8-) 1.5-3$ $(-4.7)$ by $(0.2-) 0.4-1.4 \mathrm{~cm}$, drying green to dark green, or sometimes grey; abaxial surface glabrous.

Distribution - Papua New Guinea (incl. Fergusson Island and Normanby Island).

Habitat \& Ecology - On ridges, streamsides; on substrates with good drainage; recorded with Bombax spp., Celtis spp., Chisocheton spp., and Ficus spp.; altitude $(50-) 150-1000(-1300) \mathrm{m}$.

c. var. leucocarpus (Lauterb. \& K. Schum.) A.P. Davis, stat. nov.

Amaracarpus leucocarpus (Lauterb. \& K. Schum.) Valeton (1911) 501; (1927) 117. - Litosanthes leucocarpa Lauterb. \& K. Schum. in K. Schum. \& Lauterb. (1901) 586. - Type: Lauterbach [2]113 (holo B $†$; iso K, WRSL), [Papua New Guinea], Kaiser Wilhelmsland, Oertzen-gebirge, 'Charakterpflanze des Unterholzes', 200 m, 15 May 1896.

Amaracarpus lauterbachii Valeton (1927) 120. - Type: Lauterbach 996 (holo B†; iso WRSL), Nordöstl. Neu-Guinea [Papua New Guinea], Gogol, Mittellauf, 19 Nov. 1890.

Treelet or shrub, 1-2 $\mathrm{m}$ high, puberulous to pubescent, hairs antrorse to \pm erect, $0.1-0.2(-0.3) \mathrm{mm}$ long, light brown. Stipule: apex acute. Leaves: petioles $0.5-2 \mathrm{~mm}$ long, glabrous to puberulous; leaf blades elliptic to \pm narrowly obovate, $1.5-2(-2.6)$ by $0.7-0.9(-1.2) \mathrm{cm}$, leaves usually drying grey, surface glabrous.

Distribution - Papua New Guinea (incl. New Britain and New Ireland (Mussau Island)).

Habitat \& Ecology - Poorly known. Riversides; altitude 0-60 m.

Notes - Schumann \& Lauterbach (1901) cite the specimen Lauterbach 2113 as the holotype specimen for Litosanthes leucocarpa, but no Amaracarpus material with this number has been found. There is, however, a specimen Lauterbach 113, matching the description and bearing the name L. leucocarpa, collected in Kaiser Wilhelmsland. We regard this specimen as the type (representing Lauterbach 2113) and believe that there has been a clerical error. Moreover, it is well documented that the very early collections of Lauterbach were not made in New Guinea (Van Steenis-Kruseman, 1950).

Schumann \& Lauterbach (1901) recorded the fruit colour of Litosanthes leucocarpa as white, hence the epithet for this species. It is more likely, however, that this observation represents either immature material or an erroneous observation, as Amaracarpus fruits are orange or red.

d. var. trichocarpus (Merr. \& L.M. Perry) A.P. Davis, stat. nov.

Amaracarpus trichocarpus Merr. \& L.M. Perry (1946) 225. - Type: Brass 1039 (holo A; iso BM), Papua New Guinea, Hohoro, Vailala River, 300 ft [91 m], 22 Jan. 1926.

Treelet or shrub, 0.6-1.5(-1.8) $\mathrm{m}$ high, pubescent to subhirsute, rarely hirsute, hairs antrorse to \pm erect, (0.2-)0.4-2.2 mm long, light brown to brown, or golden brown. Stipule: apex acute. Leaves: petioles $0-1(-3) \mathrm{mm}$ long, puberulous to hirsutellous; leaf blades elliptic, rarely obovate often slightly rhombic, (0.7-)0.9-3.8(-5.2) by 
$(0.2-) 0.4-1.1(-1.4) \mathrm{cm}$, usually drying green to dark green; abaxial surface glabrous to sparsely pubescent.

Distribution - Papua New Guinea (incl. New Ireland), Solomon Islands (incl. Mbava (Baga) Island, Guadalcanal Island, Malaita Island).

Habitat \& Ecology - Streamsides, river valleys, ridges valley bottoms, gorges and creeks, often on steep slopes; recorded with Castanopsis spp. and Quercus spp.; substrate: limestone, and raised coral; altitude 40-800(-1400) $\mathrm{m}$.

Note - Two fruiting specimens from the Solomons (Guadalcanal: Nakisi \& Mauriasi BSIP 8065; Malaita: Hunt 3055) are peculiar for this variety, as the fruits have enlarged, leaf-like calyx lobes. Taxonomic recognition may be necessary if this character proves to be consistent.

\section{Amaracarpus wichmannii Valeton}

Amaracarpus wichmannii Valeton in Gibbs (1917) 221. - Type: Gibbs s.n. [6185] (holo BM), [Papua Barat, Vogelkop Peninsula], Manokoeari [sic], 500 ft [152 m], Dec. 1913.

Shrub, (0.5-)0.75-1(-2) m high, glabrous to pubescent, rarely hirsutellous, hairs antrorse, (0.1-)0.2-0.3(-0.4) $\mathrm{mm}$ long, light brown; axillary brachyblasts usually numerous; leaves close together and regularly arranged in the same plane, forming flat, regular tiers of regular shape (in outline). Branchlets $1.5-2.5 \mathrm{~mm}$ diam., frequently with very fine longitudinal striations, brown, glabrous to pubescent, rarely hirsutellous. Stipules apparently free at the base, triangular, $2.5-5$ by $1-2 \mathrm{~mm}$, thinly chartaceous to membranous, glabrous or pubescent, sometimes with a tuft of hairs at the base, apex acute, with 1 seta, seta $0.5-1 \mathrm{~mm}$ long, glabrous or pubescent. Leaves: petioles $0.5-1.5(-3) \mathrm{mm}$ long, glabrous to pubescent; leaf blades obovate to narrowly obovate or obovate-elliptic, (0.7-)1.1-2(-2.2) by (0.4-)0.6-0.8(-1) cm, chartaceous, drying green to grey, base shortly attenuate to attenuate, or cuneate, frequently slightly decurrent, apex acute to broadly acute; abaxial surface: midrib glabrous to pubescent, secondary veins 4 or 5 pairs, rather indistinct or prominent, ascending at an angle of $45-60^{\circ}$, glabrous to puberulous, venation obscure to invisible; abaxial surface glabrous; adaxial surface glabrous. Inflorescences terminal on side shoots, or terminal on axillary brachyblasts (near-axillary), 1(-3)-flowered, sessile; bracts and bracteoles absent. Flowers sessile. Calyx (incl. hypanthium) c. 2.5 by $2 \mathrm{~mm}$, glabrous to puberulous, calyx lobes triangular to linear, $1.2-1.5(-2.1)$ by $0.5-1 \mathrm{~mm}$, margins puberulous. Corolla $3-5(-7)$ by $2-3$ $\mathrm{mm}$, external surface glabrous, internal surface with a ring of hairs, corolla lobes $1.5-2$ by $1 \mathrm{~mm}$. Stamens: anthers c. $0.6 \mathrm{~mm}$ long; filaments c. $0.5 \mathrm{~mm}$ long. Style c. $3.5 \mathrm{~mm}$ long. Fruit $3-4.5$ by $2-3.5 \mathrm{~mm}$, sessile; calyx $1-1.5 \mathrm{~mm}$ long. Pyrenes $3-5$ by $2-4.5 \mathrm{~mm}$.

Distribution - Papua Barat (incl. Vogelkop Peninsula), Papua New Guinea (incl. Normanby Island).

Habitat \& Ecology - On rocks, steep ridges and along creeks; recorded with Castanopsis spp.; substrate: limestone (incl. open karst areas), granite and clay; scattered to locally common; altitude 10-750 m.

Note - Amaracarpus wichmannii is very similar to A. nymanii, as both species have leaves of similar size and shape and stipules with an acute apex (sometimes possessing a single, very small seta). The latter species differs by its hirsutellous to pubescent branchlets, often numerous brachyblasts and conspicuously congested leaves. 


\section{Amaracarpus nymanii Valeton}

Amaracarpus nymanii Valeton (1927) 119 (as 'nymannii'). - Type: Nyman 104 (holo B †), Nordöstl. Neu-Guinea [Papua New Guinea], Stephansort, Jan. 1899. - Neotype: Brass 24011 (neotype A, selected here; isoneotypes K, L, US), Papua New Guinea, Milne Bay District, Peria Creek, Kwagira River, 50 m, 17 Aug. 1953.

Shrub, (0.6-)1-1.75(-2) $\mathrm{m}$ high, hirsutellous to pubescent, hairs \pm erect, $0.6-1 \mathrm{~mm}$ long, brown to dark brown; axillary brachyblasts numerous; leaves very close together and regularly arranged in the same plane, forming flat, dense regular tiers, of regular shape (in outline). Branchlets 1.5-2.4 mm diam., smooth, brown to dark brown, hirsutellous to pubescent. Stipules \pm free at the base, \pm triangular, $1.7-3.5$ by $1-1.5$ $\mathrm{mm}, 2$-veined, membranous, glabrous but veins pubescent to puberulous, apex acute or with 1 seta, seta, if present, $0.5 \mathrm{~mm}$ long, pubescent to puberulous. Leaves: petioles $(0.5-) 1-2(-4) \mathrm{mm}$ long, pubescent to hirsutellous; leaf blades obovate, rarely narrowly elliptic to narrowly obovate, (0.7-)1-1.8(-2.4) by $(0.3-) 0.4-1 \mathrm{~cm}, \pm$ chartaceous, drying grey, greyish or green, base cuneate to narrowly cuneate, apex rounded to obtuse, rarely acute; abaxial surface: midrib glabrous to puberulous, secondary veins $3-5(-6)$ pairs, manifest to obscure, ascending at an angle of c. $45^{\circ}$, glabrous, venation manifest or obscure; abaxial surface glabrous; adaxial surface glabrous. Inflorescences terminal on side shoots, or terminal on axillary brachyblasts (near-axillary), 1-flowered, sessile; bracts and bracteoles absent. Flowers sessile. Calyx (incl. hypanthium) c. 4 by $3 \mathrm{~mm}$, glabrous, calyx lobes triangular, $0.8-2$ by $0.5-1 \mathrm{~mm}$, glabrous. Corolla $8-10$ by $3-4 \mathrm{~mm}$, external surface glabrous, internal surface with a ring of hairs, corolla lobes $3-3.5$ by $1-1.5 \mathrm{~mm}$. Stamens: anthers c. $0.5 \mathrm{~mm}$ long; filaments c. $0.4 \mathrm{~mm}$ long. Style c. $3.2 \mathrm{~mm}$ long. Fruit $5-7$ by $3.5-6 \mathrm{~mm}$, sessile; calyx c. $0.5 \mathrm{~mm}$ long. Pyrenes c. 3.5 by $2.2 \mathrm{~mm}$.

Distribution - Papua New Guinea (incl. Goodenough Island).

Habitat \& Ecology - Understorey of evergreen humid forest and also found in coastal scrub; recorded with Casuarina spp. and Quercus spp.; near rivers, streamsides; substrate: limestone, sometimes rocky; sometimes locally common; altitude 50-220(-?2515) m.

Note - Even though we have not seen the holotype of this species it is clear from the original description (Valeton, 1927) that the name A. nymanii should be used to represent this entity. Valeton (1927) spells the epithet for this species as 'nymannii', but we have changed this to nymanii to accord with the collector's name (E.O.A. Nyman). After an exhaustive search for isotypes of A. nymanii (Nyman 104) we have come to the conclusion that the collection was a unicate (the holotype), and was destroyed in Berlin. It also appears that all the other material on which the taxon was based (if any ever existed) is missing, again presumably destroyed in Berlin. Valeton (1927: 120) cites a second specimen (Schlechter 16090, K, L) as perhaps the same ('Vielleicht ebenfalls') as A.nymanii, and annotated the collection as 'Amaracarpus (aff. Nymanii Val) [sic.]'. Merrill \& Perry (1946: 225) suggest that the Schlechter specimen is very close to their A. calcicola, and we confirm that it belongs to A. calcicola, not A. nymanii. In conclusion, it appears that no original material of this species exists, and so we have selected a neotype for A. nymanii (see above). 


\section{Amaracarpus novo-guineensis (Warb.) Valeton}

Amaracarpus novo-guineensis (Warb.) Valeton (1927) 118. - Litosanthes novo-guineensis Warb. (1891) 442; K. Schum. \& Lauterb. (1901) 585. - Type: Hellwig 231 (lectotype BO, selected here; isolectotype K), Neu-Guinea [Papua New Guinea], Kaiser Wilhelmsland, 13 Jan. 1889.

Shrub, height unknown, puberulous to minutely puberulous, or \pm glabrous, hairs antrorse to \pm erect $<0.1-0.1 \mathrm{~mm}$ long, light brown to brown; axillary brachyblasts present; leaves close together and regularly arranged in the same plane, forming flat, regular tiers of irregular shape (in outline). Branchlets (0.5-)1-1.5 mm diam., \pm smooth, brown, puberulous to minutely puberulous. Stipules connate at the base or free, broadly ovate to narrowly triangular, $1.5-4$ by $0.7-1 \mathrm{~mm}$, membranous to subcoriaceous, puberulous, apex acute. Leaves: petioles $0.5-1 \mathrm{~mm}$ long, glabrous to puberulous; leaf blades usually elliptic to broadly elliptic, $(0.4-) 0.6-1.1$ by $(0.2-) 0.3-0.6 \mathrm{~cm}$, chartaceous, usually drying light green to green, base cuneate to narrowly cuneate, apex acute to cuneate; abaxial surface: midrib puberulous to glabrous, secondary veins 3 or 4 pairs, obscure to obvious, ascending at an angle of $30-45^{\circ}$, glabrous, venation invisible; abaxial surface glabrous; adaxial surface glabrous. Inflorescences terminal at the apex of side shoots or terminal on axillary brachyblasts (near-axillary), 1-flowered, sessile; bracts and bracteoles absent. Flowers sessile. Calyx (incl. hypanthium) $1-1.2$ by $0.9-1 \mathrm{~mm}$, glabrous, calyx lobes deltate to triangular, c. 0.7 by $0.5 \mathrm{~mm}$ long, margins puberulous. Corolla $2-3.5$ by $1.3-1.5 \mathrm{~mm}$, external surfaces puberulous or glabrous, internal surface with a ring of hairs, corolla lobes c. $0.5 \mathrm{~mm}$ long. Stamens: anthers c. $0.6 \mathrm{~mm}$ long; filaments c. $0.3 \mathrm{~mm}$ long. Style not seen. Fruit c. 3 by $2.5 \mathrm{~mm}$ (immature), sessile; calyx c. $0.7 \mathrm{~mm}$ long. Pyrenes not seen.

Distribution - Papua Barat and Papua New Guinea.

Habitat \& Ecology - Poorly known. Altitude 1000-2400(-2600) m.

Note - Warburg (1891) based Litosanthes novo-guineensis on two specimens collected in northern Papua New Guinea (Kaiser-Wilhelmsland) by F. Hellwig (Hellwig 231 and 523). We have chosen the specimen Hellwig 231 as the lectotype.

\section{Amaracarpus compactus Merr. \& L.M. Perry}

Amaracarpus compactus Merr. \& L.M. Perry (1946) 227. - Type Brass 4133 (holo A; iso L, NY), Papua New Guinea, Mt Tafa, Central Division, 2100 m, May-Sept. 1933.

Amaracarpus simulans Merr. \& L.M. Perry (1946) 228. - Type: Brass 10522 (holo A; iso BM, L), Irian Jaya [Papua Barat], 9 km NE of Lake Habbema, 2800 m, Oct. 1938.

Treelet or shrub, $0.5-4(-6) \mathrm{m}$ high, puberulous to pubescent, sometimes glabrous, hairs antrorse to \pm erect, $<0.1-0.2 \mathrm{~mm}$ long, brown to dark brown; axillary brachyblasts usually absent, sometimes few; leaves rather irregularly arranged, forming flat \pm regular tiers of irregular shape (in outline). Branchlets 0.5-1.5(-2.5) $\mathrm{mm}$ diam., \pm smooth, brown, puberulous to pubescent. Stipules connate at the base and sometimes for more than $1 / 2$ their length, or free, broadly obovate, \pm square to oblong, or triangular, 1-2.7 $(-3.5)$ by $0.7-1.5 \mathrm{~mm}$, membranous, puberulous or glabrous, apex acute to broadly acute with 1 or 2 short tuft of hairs or with 1 seta, seta, if present, $(0.2-) 0.5-0.7 \mathrm{~mm}$ long, puberulous to glabrous. Leaves: petioles $(0-) 0.5-2(-2.5) \mathrm{mm}$ long, puberulous to pubescent, or glabrous; leaf blades elliptic-rhombic, or rhombic-narrowly obovate to rhombic-obovate, $(0.3-) 0.4-1.3$ by $(0.1-) 0.2-0.6(-1) \mathrm{cm}$, chartaceous, usually 
drying dark green to brown, or blackish, base cuneate to narrowly cuneate, sometimes decurrent, apex abruptly acuminate, or acute to obtuse; abaxial surface: midrib puberulous or glabrous, secondary veins 3 or 4 (or 5) pairs, obscure to manifest, ascending at an angle of $30-45^{\circ}$, glabrous, venation obscure to invisible; abaxial surface glabrous; adaxial surface glabrous. Inflorescences terminal at the apex of side shoots and/or the axillary brachyblasts (near-axillary), 1-flowered, sessile; bracts and bracteoles absent. Flowers sessile. Calyx (incl. hypanthium) $2-5$ by $1.5-2.5 \mathrm{~mm}$, glabrous, calyx lobes deltate to triangular, or broadly elliptic, $0.5-1.5$ by $0.6-1(-1.5) \mathrm{mm}$ long, glabrous. Corolla $(2.5-) 3-5(-7)$ by $2.5-5.5 \mathrm{~mm}$, external surface glabrous to sparsely puberulous, internal surface with a ring of hairs or glabrous, corolla lobes (0.5-)1-2.5 by $0.7-1.5 \mathrm{~mm}$. Stamens: anthers $0.5-1 \mathrm{~mm}$ long; filaments $0.2-0.3 \mathrm{~mm}$ long. Style (2-)3-6 mm long. Fruit 3-7 by $2.5-4 \mathrm{~mm}$, sessile; calyx $0.7-1 \mathrm{~mm}$ long. Pyrenes $4-4.5$ by $3.5-4 \mathrm{~mm}$.

Distribution - Papua Barat and Papua New Guinea (incl. Fergusson Island).

Habitat \& Ecology - Valley bottoms; substrate: limestone; locally frequent to common; altitude 1200-2800 m.

\section{Amaracarpus heteropus Valeton - Fig. 4, 5}

Amaracarpus heteropus Valeton (1912) 769; (1909-1914) pl. 128. - Type: Gjellerup 264 (lectotype L, selected here; isolectotypes BO, L), N.N. Guinea [Papua Barat], Tami-river, $\pm 50 \mathrm{~m}$, 8 July 1910.

Amaracarpus longifolius Valeton (1912) 770; (1909-1914) pl. 129, nom. illegit., non Amaracarpus longifolius Elmer. - Type: Gjellerup 327 (lectotype BO, selected here; isolectotypes BO, L), Nord-n. Guinea, [Papua Barat], Augusta River, \pm 60 m, 5 Oct. 1910.

Amaracarpus lanceolatus Valeton (1927) 115. - Type: Lam 1084 (lectotype L, selected here; isolectotypes L, U), Nova Guinea neerlandica [Papua Barat] in reg. flum. Mamberamo, Prauwenbivak, 180 m, 6 Sept. 1920.

Amaracarpus corymbosus Valeton (1927) 115. - Type: Feuilletau de Bruyn 47 (lectotype BO, selected here; isolectotypes K, L), Nova Guinea neerlandica meridonalis [Papua Barat], 20 June 1914.

Amaracarpus urophyllus Merr. \& L.M. Perry (1946) 221. - Type: Brass 4998 (holo A; iso NY), Papua New Guinea, Mount Tafa, Central Division, 2400 m, Sept. 1933.

Shrub or treelet, 1-2 m high, glabrous to pubescent, hairs \pm erect to antrorse, $<0.1-0.5(-1) \mathrm{mm}$ long, brown; axillary brachyblasts usually present; leaves regularly arranged in the same plane, but not close together, forming flat but irregular shaped tiers (in outline). Branchlets $1.5-3 \mathrm{~mm}$ diam., \pm smooth, brown, glabrous to pubescent. Stipules connate at the base to $1 / 3$ to $1 / 2$ of their length, rectangular or triangular to narrowly ovate, $(2.5-) 3.5-9.5(-11)$ by $(1.8-) 2.5-2.7 \mathrm{~mm}, 2$-veined, membranaceous to chartaceous, glabrous to pubescent, apex truncate to acute, with 2 prominent setae, setae (1.5-)3-7.5 mm long, glabrous to pubescent. Leaves: petioles 3-5 mm long, glabrous to puberulous; leaf blades \pm elliptic to \pm narrowly ovate, elliptic-obovate, or narrowly elliptic, $(3.2-) 5.5-14.2$ by $(0.9-) 1.5-4.2(-5.7) \mathrm{cm}$, chartaceous, drying green to dark green, or greyish to grey, base cuneate to obtuse, apex subcaudate, rarely acute, cauda $0.4-1 \mathrm{~cm}$ long; abaxial surface: midrib glabrous or puberulous, secondary veins (6-) 8-10(-12) pairs, prominent, ascending at an angle of $30-45^{\circ}$, glabrous to puberulous, venation obscure to manifest; abaxial surface glabrous; adaxial surface glabrous. Inflorescences terminal on axillary brachyblasts (near-axillary), or axillary 


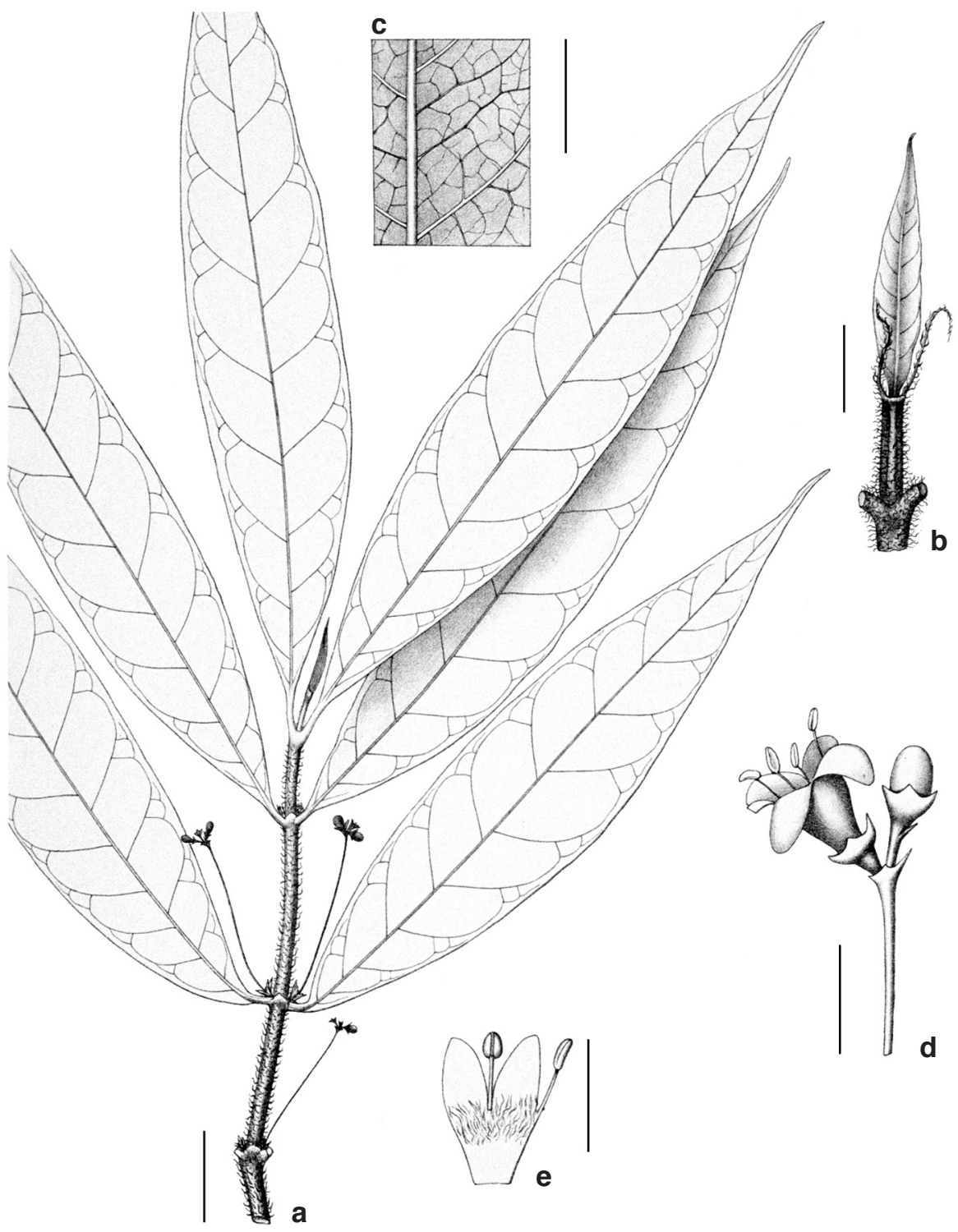

Fig. 4. Amaracarpus heteropus Valeton. a. Habit, showing terminal inflorescences on much reduced axillary brachyblasts (near axillary), the lowest inflorescence pair more or less axillary; b. detail of shoot apex, showing stipule with two distinct setae (2nd leaf pair removed); c. detail leaf venation; d. part of inflorescence, showing peduncle and flowers; e. section of corolla (internal view), showing two stamens inserted within the ring of corolla throat hairs. Drawn by R. Natadipoera; reproduced from Nova Guinea 8, 3 (1909-1914) pl. 129 (modified for publication here). - Scale bars: a = 2 $\mathrm{cm} ; \mathrm{b}, \mathrm{c}=2 \mathrm{~mm} ; \mathrm{d}=4 \mathrm{~mm} ; \mathrm{e}=3 \mathrm{~mm}$. 


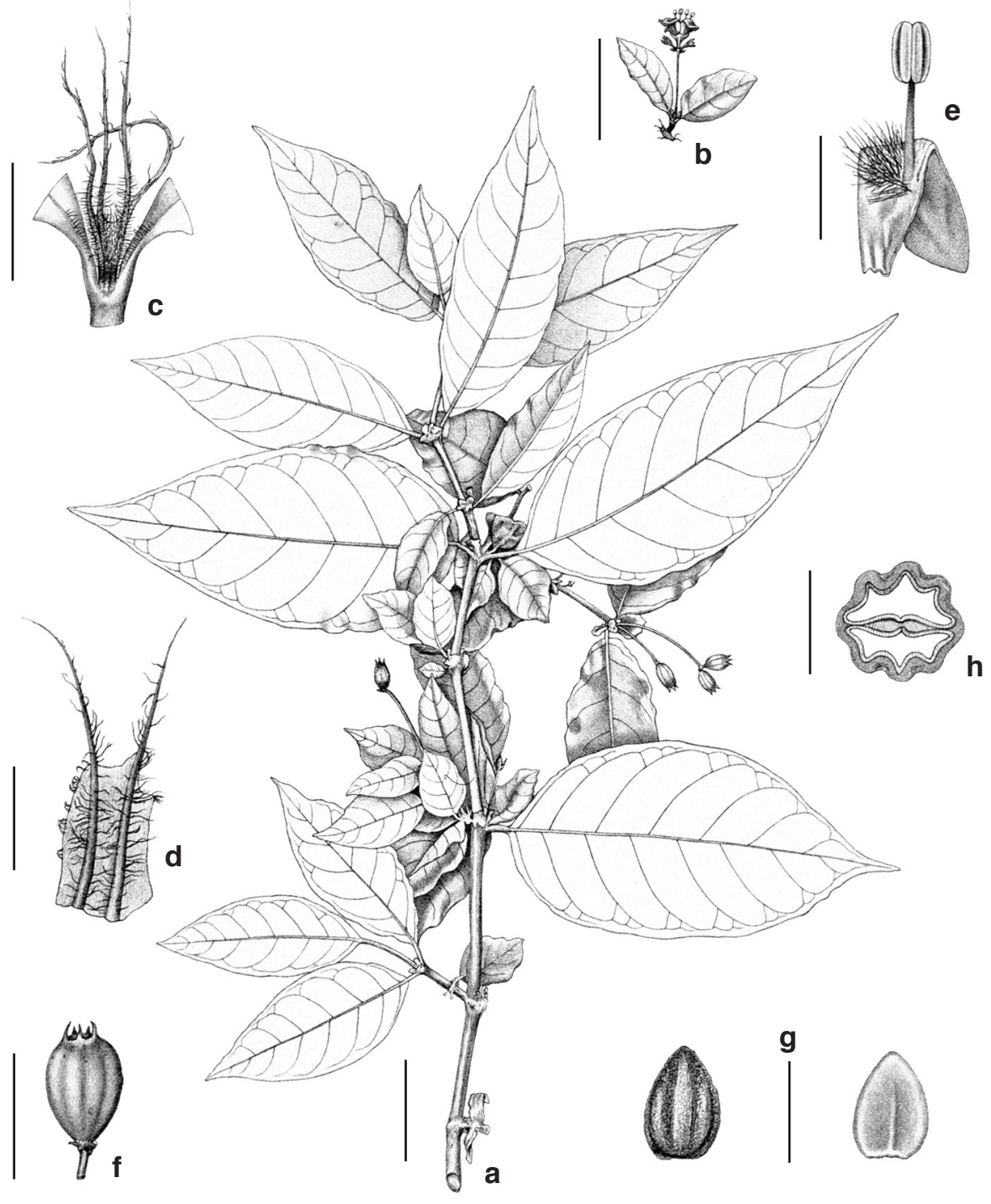

Fig. 5. Amaracarpus heteropus Valeton. a. Habit, showing terminal inflorescences on axillary brachyblasts (near axillary); b. detail of (secondary) axillary side shoots (axillary brachyblasts), showing reduced leaves and pedunculate inflorescence; $c$. stipules; d. mature stipule with two setae; e. section of corolla (internal view), showing one stamen inserted within the ring of corolla throat hairs; f. fruit; g. pyrene, dorsal (abaxial) and ventral (adaxial) views (left to right); h. transverse section through fruit, showing ridged dorsal surface of pyrene. Drawn by R. Natadipoera; reproduced from Nova Guinea 8, 3 (1909-1914) pl. 128 (modified for publication here). - Scale bars: $\mathrm{a}=2 \mathrm{~cm}$; b = 1.3 $\mathrm{cm} ; \mathrm{c}, \mathrm{h}=3 \mathrm{~mm} ; \mathrm{d}=2 \mathrm{~mm} ; \mathrm{e}=1.8 \mathrm{~mm} ; \mathrm{f}, \mathrm{g}=5 \mathrm{~mm}$. 
in the first or second leaf pair, (1-)2-5(-7)-flowered simple cymes or few-branched simple (compound) cymes, pedunculate; peduncle (0.2-) $0.7-4.6 \mathrm{~cm}$ long, glabrous to puberulous; second order inflorescence branches present or absent, if present $0.2-0.5$ cm long; bracts 2 per peduncle, opposite, narrowly triangular to linear, (0.5-)1-3.5 $\mathrm{mm}$ long, sometimes fallen; bracteoles 2 per flower, opposite, linear, 0.2-0.6 mm long, or absent. Flowers sessile or pedicellate; pedicel, if present $0.5-1 \mathrm{~mm}$ long. Calyx (incl. hypanthium) $1-2.7$ by $1.5-2(-3) \mathrm{mm}$, glabrous, calyx lobes deltate to triangular, (0.4-) $0.6-1$ by $0.4-0.7 \mathrm{~mm}$, glabrous. Corolla $1.5-2.6(-5)$ by $1.5-3.5$ $\mathrm{mm}$; external surface glabrous, internal surface with a ring of hairs or rarely glabrous, corolla lobes $1-2.7$ by $0.5-0.7 \mathrm{~mm}$. Stamens: anthers $(0.3-) 0.5-0.7(-1) \mathrm{mm}$ long; filaments $0.4-0.9(-1.7) \mathrm{mm}$ long. Style $1.4-2.5 \mathrm{~mm}$ long. Fruit (3.2-) $4.5-8$ by $3-3.8$ $\mathrm{mm}$, pedicel, if present $0.5-1.1 \mathrm{~mm}$ long; calyx $1.5-2.5 \mathrm{~mm}$ long, or falling. Pyrenes $5-6.5$ by $2.5-4.5 \mathrm{~mm}$.

Distribution - Papua Barat, Papua New Guinea, Australia (North Queensland).

Habitat \& Ecology - Coastal plains, edges of swamps; Recorded with Celtis spp., Ficus spp., Oncosperma sp., Pometia spp., Rubiaceae spp., Sterculia spp.; substrate: limestone, limestone with thin cover of clay; locally frequent; altitude 10-780 m.

Notes - Amaracarpus heteropus could be confused with A. attenuatus, as both species have relatively large leaves and long pedunculate inflorescences. These two species can be easily distinguished on the basis that $A$. heteropus has stipules with two very prominent setae, whereas the stipules of $A$. attenuatus are divided (bifid) into two narrowly (often seta-like) triangular points.

The two figures of $A$. heteropus reproduced here (see Fig. 4,5) give some indication of the variability within one species, particularly in the degree to which the inflorescences can vary within a single species (i.e. terminal on axillary brachyblasts (Fig. 5) to near axillary and axillary (Fig. 4)). It should be noted, however, that Fig. 5 is somewhat inaccurate as the axillary brachyblasts A. heteropus do not possesses quite so many leaves.

Amaracarpus longifolius Valeton is a later homonym of A. longifolius Elmer (= Psychotria linearis Bartl. ex DC.).

\section{Amaracarpus acuminatus $\mathrm{S}$. Moore}

Amaracarpus acuminatus S. Moore (1923) 27. - Type: Forbes 657 (holo BM; iso L), Papua New Guinea, Sogeri, 1885-1886.

[Amaracarpus forbesii Valeton ined., in schedae.]

Shrub, 1-3.5 m high, puberulous to pubescent, hairs antrorse to erecto-patent, $0.1-0.2$ mm long, brown to dark brown; axillary brachyblasts few; leaves close together and regularly arranged in the same plane, forming flat, regular tiers of irregular shape (in outline). Branchlets $0.4-1 \mathrm{~mm}$ diam., \pm smooth, dark brown, puberulous to pubescent. Stipules connate for most of their length, \pm oblong to square, $1.2-2.5$ by $0.7-1 \mathrm{~mm}$, membranous to chartaceous, glabrous to puberulous, apex truncate to obtuse, with 2 setae, or rarely acute and \pm lacking setae, setae, if present, $0.5-0.7 \mathrm{~mm}$ long, glabrous to puberulous. Leaves: petioles $0-0.6(-3) \mathrm{mm}$ long, glabrous to puberulous; leaf blades rhombic to elliptic-rhombic, or slightly obovate, $0.5-1.9$ by $(0.3-) 0.5-1.1(-1.3) \mathrm{cm}$, often slightly asymmetric, chartaceous to subcoriaceous, drying green to blackish, 
or grey, base cuneate to narrowly cuneate, apex abruptly acuminate to acute; abaxial surface: midrib glabrous to sparsely puberulous, secondary veins (3-)4-5(-8) pairs, manifest to obscure, ascending at an angle of $30-45^{\circ}$, glabrous to sparsely puberulous, venation obscure to \pm invisible; abaxial surface glabrous; adaxial surface glabrous. Inflorescences terminal at the apex of the side shoots, or terminal on axillary brachyblasts (near-axillary) or axillary, (2- or) 3-flowered umbels, pedunculate; peduncle $0.4-1.3 \mathrm{~cm}$ long, elongating during development, glabrous to puberulous; bracts 2 per peduncle, opposite, narrowly triangular to linear or cuspidate, c. 1 by $0.3 \mathrm{~mm}$; bracteoles $2-5$ per flower, sometimes forming a calyx-like structure, $1-1.5$ by $1 \mathrm{~mm}$, lobes triangular, c. 0.5 mm long, glabrous to puberulous. Flowers sessile. Calyx (incl. hypanthium) 1-2.5 by $1 \mathrm{~mm}$, glabrous, calyx lobes deltate to triangular, $0.2-0.7 \mathrm{~mm}$ long, glabrous. Corolla $1.5-2$ by $2 \mathrm{~mm}$, external and internal surfaces glabrous, corolla lobes c. 0.7 by $0.7 \mathrm{~mm}$. Stamens: anthers $0.2-0.5 \mathrm{~mm}$ long; filaments $0.2-0.3 \mathrm{~mm}$ long. Style $0.2-0.7 \mathrm{~mm}$ long. Fruit $4-5$ by $3-4 \mathrm{~mm}$; calyx $0.2-0.5 \mathrm{~mm}$ long. Pyrenes c. 4 by $3 \mathrm{~mm}$.

Note - We consider that A. acuminatus, A. mesophyllus, and A. pullei represent a single species. There are, however, some morphological and ecological (e.g. altitude) differences between A. acuminatus and A. pullei, and we have recognized two subspecies: subsp. acuminatus and subsp. pullei.

\section{KEY TO THE SUBSPECIES}

1a. Secondary veins 3 or 4 pairs, obscure; inflorescence peduncle glabrous . . . . . . $\ldots \ldots \ldots \ldots \ldots \ldots \ldots \ldots \ldots \ldots \ldots \ldots \ldots \ldots \ldots \ldots \ldots \ldots$. subsp. acuminatus

b. Secondary veins $4-5(-8)$ pairs, prominent to weak; inflorescence peduncle pu-

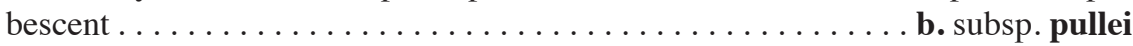

\section{a. subsp. acuminatus}

Shrub, 1-3 m high. Branchlets $0.4-1 \mathrm{~mm}$ diam., often crooked in a zigzag pattern. Leaves: secondary veins 3 or 4 pairs, obscure. Inflorescences: peduncle $0.5-0.8 \mathrm{~cm}$ long, glabrous; bracts narrowly triangular to linear.

Distribution - Papua Barat, Papua New Guinea.

Habitat \& Ecology — Poorly known. Recorded with Fagus spp.; altitude 450-1900 $(-2680) \mathrm{m}$.

b. subsp. pullei (Valeton) A.P. Davis, stat. nov.

Amaracarpus pullei Valeton (1927) 114. - Type: Pulle 1219 (lectotype L, selected here; isolectotypes K, L, U), [Papua Barat], Noordriver, Kloof bivouac, 40 m, 24 March 1913.

Amaracarpus mesophyllus Valeton (1927) 113. - Type: Lam 544 (lectotype L, selected here; isolectotypes K, L, U), Noord N. Guinea [Irian Jaya], Pionierbivak [Pionier bivouac], 70 m, 4 July 1920.

Shrub, 1.5-3.5 m high. Branchlets $0.7-1 \mathrm{~mm}$ diam., usually straight. Leaves: secondary veins 4-5(-7-8) pairs, prominent to weak. Inflorescences: peduncle $0.4-1.3 \mathrm{~cm}$ long, pubescent; bracts triangular to cuspidate.

Distribution - Papua Barat, Papua New Guinea.

Habitat \& Ecology — Recorded with Agathis spp.; substrate: clay; altitude 70-580 $(-1050) \mathrm{m}$. 


\section{Amaracarpus doormaniensis Valeton}

Amaracarpus doormaniensis Valeton (1927) 114 (as 'doormanniensis'). - Type: Lam 1990 (lectotype $\mathrm{BO}$, selected here; isolectotypes $\mathrm{K}, \mathrm{L}, \mathrm{U})$, Nova Guinea neerlandica [Papua Barat], Mamberamo, alt. $2480 \mathrm{~m}$, pr. in mont. Doorman, 13 Feb. 1920.

Shrub, c. $2.5 \mathrm{~m}$ high, puberulous to pubescent, hairs antrorse to erecto-patent, $0.1-0.2$ $\mathrm{mm}$ long, brown to dark brown; axillary brachyblasts few or absent; leaves close together and regularly arranged in the same plane, forming flat, regular tiers of irregular shape (in outline). Branchlets 0.7-1.5 mm diam., \pm smooth, dark brown, pubescent. Stipules connate for most of their length, \pm oblong, 2-3 by $0.7-1 \mathrm{~mm}$, subcoriaceous, glabrous, apex truncate, truncate to acute, with ( 1 or) 2 setae, setae $0.5-0.7 \mathrm{~mm}$ long, pubescent to puberulous. Leaves: petioles $0-0.5 \mathrm{~mm}$ long, glabrous; leaf blades rhombic to elliptic-rhombic, or rhombic-narrowly obovate, $(0.7-) 0.9-1.4$ by $0.3-0.5(-0.7)$ $\mathrm{cm}$, often slightly asymmetric, chartaceous, usually drying dark green, base narrowly cuneate and sometimes decurrent, apex abruptly acuminate; abaxial surface: midrib glabrous, secondary veins 3-5 pairs, manifest to obscure, ascending at an angle of $45-60^{\circ}$, glabrous, venation obscure to \pm invisible; abaxial surface glabrous; adaxial surface glabrous. Inflorescences terminal at the apex of reduced side shoots or terminal on axillary brachyblasts (near-axillary) or axillary, 1-flowered, pedunculate; peduncle (0.1-) 0.3-0.8 cm long, elongating during development, glabrous; bracts 2 per peduncle, opposite, narrowly triangular to triangular, linear, or elliptic (subfoliaceous), 0.7-1.2 $(-2)$ by $0.3-0.7(-1) \mathrm{mm}$; bracteoles absent. Flowers subsessile to pedicellate; pedicel 0.5-3.5(-5) mm long. Calyx (incl. hypanthium) c. 1.5 by $1 \mathrm{~mm}$, glabrous, calyx lobes deltate to triangular, $1-1.5$ by $0.3 \mathrm{~mm}$ long, glabrous. Corolla imperfectly known, $2-3$ by $1-1.5 \mathrm{~mm}$, external and internal surface glabrous, corolla lobes $2-3$ by $1 \mathrm{~mm}$. Stamens: anthers c. $0.6 \mathrm{~mm}$ long; filaments c. $1 \mathrm{~mm}$ long. Style c. $0.7 \mathrm{~cm}$ long. Fruit $5.5-7$ by $4-4.5 \mathrm{~mm}$, pedicel $3.5-5 \mathrm{~mm}$ long; calyx c. $1 \mathrm{~mm}$ long. Pyrenes $5.5-6$ by $4-4.5 \mathrm{~mm}$.

Distribution - Papua Barat and Papua New Guinea. Only recorded from two localities: Mt Doormantop [Angemuk] and the Hunstein Range (Mt Samsai).

Habitat \& Ecology - Poorly known. Ridges; altitude 900-2480 m.

Notes - Valeton (1927) did not cite any specimens in his description of A. doormaniensis but we assume that the original material comprises two specimens collected by H.J. Lam (Lam 1482 and 1990) from Mt Doorman, both of which were annotated by Valeton ('Amaracarpus doormanniensis [sic] Val. N. sp.'). We have selected the specimen Lam 1990 to serve as the lectotype.

Amaracarpus doormaniensis is close to A. acuminatus, but can be separated by its one-flowered inflorescences; A. acuminatus has three- or rarely two-flowered inflorescences.

\section{Amaracarpus xanthocarpus Merr. \& L.M. Perry}

Amaracarpus xanthocarpus Merr. \& L.M. Perry (1946) 226. - Type: Brass 12861 (holo A!; iso BM,

L), Irian Jaya [Papua Barat], 6 km SW of Bernhard Camp, Idenburg River, 1200 m, Feb. 1939.

Treelet or shrub, 2-4 m high, puberulous to pubescent, hairs \pm erect to antrorse, $0.2-0.3$ mm long, brown; axillary brachyblasts usually numerous; leaves close together and 
regularly arranged in the same plane, forming flat, regular tiers of \pm regular shape (in outline). Branchlets $0.5-0.7 \mathrm{~mm}$ diam., \pm smooth, light brown, puberulous to pubescent. Stipules connate for c. 1/2 their length, square or oblong, 1-2 by $1 \mathrm{~mm}$, membranous, glabrous to puberulous, apex truncate to rounded, with 2 setae, setae c. $1 \mathrm{~mm}$ long, puberulous. Leaves: petioles 1-1.5 mm long, puberulous; leaf blades elliptic to broadly elliptic, elliptic-rhombic, or \pm obovate, $0.7-1.1$ by $0.4-0.8 \mathrm{~cm}$, chartaceous, drying green to dark green, base cuneate to slightly rounded, apex acute to abruptly acuminate; abaxial surface: midrib puberulous, secondary veins $3-5$ pairs, manifest, ascending at an angle of c. $45^{\circ}$, glabrous, venation obscure to invisible; abaxial surface glabrous; adaxial surface glabrous. Inflorescences terminal at the apex of the side shoots and terminal on axillary brachyblasts (near-axillary), 3-5(-7)-flowered simple cymes, sessile; bracts 2 per cyme, opposite, linear, $1-1.5 \mathrm{~mm}$ long, with two elongated lobe-like processes at the base; bracteoles absent. Flowers sessile. Calyx (incl. hypanthium) 2-3 by $2-3 \mathrm{~mm}$, glabrous, calyx lobes \pm deltate, $0.5-1$ by $0.5-1 \mathrm{~mm}$, glabrous. Corolla imperfectly known (only buds seen), $1-1.5$ by $2 \mathrm{~mm}$, internal and external surfaces glabrous, corolla lobes c. $0.5 \mathrm{~mm}$ long. Stamens: anthers $0.3-0.5 \mathrm{~mm}$ long; filaments $0.2-0.3 \mathrm{~mm}$ long. Style c. $1.5 \mathrm{~mm}$ long. Fruit $5-6$ by $4-5 \mathrm{~mm}$, sessile; calyx $0.7-0.9$ $\mathrm{mm}$ long. Pyrenes c. 4 by $2.5 \mathrm{~mm}$.

Distribution - Papua Barat. Known only from two collections along the Idenburg River (Brass 12393, 12861).

Habitat \& Ecology - Poorly known. Occasional; altitude 1200-1500 m.

Note - Amaracarpus xanthocarpus is very similar to A. idenburgensis, but can be separated by having stipules with two setae at the apex, slightly larger $(0.7-1.5 \mathrm{~cm}$ long) chartaceous leaves, and pedicellate flowers. Amaracarpus idenburgensis has stipules with an acute to obtuse apex (i.e. lacking setae), subcoriaceous leaves $(0.5-0.9 \mathrm{~cm}$ long) and sessile flowers.

\section{Amaracarpus major (Valeton) A.P. Davis, stat. nov.}

Amaracarpus braunianus (Warb.) Valeton var. major Valeton (1927) 124. - Litosanthes brauniana Warb. (1891) 441. - Type: Schlechter 17221 (holo B†; iso L), Nordöstl. Neu-Guinea [Papua New Guinea], Kaiser-Wilhelmsland, Kani, c. 1100 m, 20 Jan. 1908.

Shrub, terrestrial or subepiphytic, $0.9-1.5 \mathrm{~m}$ high, glabrous to puberulous, hairs \pm erect to antrorse, $<0.1-0.2 \mathrm{~mm}$ long, brown; axillary brachyblasts few to \pm absent; leaves regularly arranged in the same plane, but not close together, forming flat but irregular shaped tiers (in outline). Branchlets 1-2.5 mm diam., \pm smooth, brown, glabrous to puberulous. Stipules connate in the lower part, oblong to triangular or narrowly triangular, $2-5$ by $0.5-1.2 \mathrm{~mm}$, membranous to chartaceous, glabrous, apex acute or with $1 \mathrm{seta}$, seta, if present, $0.2-0.4 \mathrm{~mm}$ long, glabrous or puberulous. Leaves: petioles (1-)3-5 mm long, glabrous; leaf blades obovate to narrowly obovate, \pm elliptic, or nearly rhombic, $(1.5-) 1.7-3.8$ by $0.7-1.2(-1.6) \mathrm{cm}$, chartaceous, drying green to greyish, base narrowly cuneate, slightly decurrent, apex acute to abruptly caudate; abaxial surface: midrib glabrous to puberulous, secondary veins (5 or) 6 or 7 pairs, indistinct to prominent, ascending at an angle of $30-45^{\circ}$, glabrous, venation obscure to manifest; abaxial surface glabrous; adaxial surface glabrous. Inflorescences terminal at the apex of side shoots, 1-3(-5)-flowered simple cymes, pedunculate; peduncle 
$1.2-1.9 \mathrm{~cm}$ long, glabrous; bracts 2 per peduncle, opposite, narrowly triangular, c. $0.5 \mathrm{~mm}$ long; bracteoles absent. Flowers sessile. Calyx (incl. hypanthium) 1.5-2.5 by $1.5-2 \mathrm{~mm}$, glabrous, calyx lobes deltate, $0.3-0.7$ by $0.6 \mathrm{~mm}$, glabrous. Corolla $1.5-2.2$ by $1.2-2 \mathrm{~mm}$, external and internal surface glabrous, corolla lobes c. 0.6 by $0.8 \mathrm{~mm}$. Stamens: anthers $0.3-0.7 \mathrm{~mm}$ long; filaments $0.9-1.1 \mathrm{~mm}$ long. Style c. 1.5 mm long. Fruit unknown.

Distribution - Papua Barat and Papua New Guinea.

Habitat \& Ecology - Poorly known. Altitude 1000-1300 m.

Note - The species A. braunianus is unknown to us: we could not find any specimen of this species and it seems likely that all the material cited by Warburg (1891) and Valeton (1927) was destroyed in Berlin. We propose that A. braunianus var. major be elevated to species rank as we believe it is illogical to assign it to a species (i.e. A. braunianus) that is likely to remain unknown.

\section{Amaracarpus idenburgensis Merr. \& L.M. Perry}

Amaracarpus idenburgensis Merr. \& L.M. Perry (1946) 227. - Type: Brass 12674 (holo A; iso BM, L), Irian Jaya [Papua Barat], 18 km SW of Bernhard Camp, Idenburg River, 2150 m, Feb. 1939.

Treelet or shrub, (1-)2-3 m high, puberulous to pubescent, hairs \pm erect, $0.2-0.3 \mathrm{~mm}$ long, brown; axillary brachyblasts present; leaves close together and regularly arranged in the same plane, forming flat, regular tiers of \pm regular shape (in outline). Branchlets 0.6-1 mm diam., \pm smooth, dark brown, puberulous to pubescent. Stipules connate for c. $1 / 2$ their length, oblong to triangular, $1-2.5(-3)$ by $0.6-1 \mathrm{~mm}$, membranous to subcoriaceous, puberulous to pubescent, apex obtuse to acute. Leaves: petioles (0.5-) 1-1.5 mm long, puberulous to pubescent; leaf blades ovate, ovate-rhombic, or \pm elliptic, $0.5-0.9$ by $0.3-0.6(-1) \mathrm{cm}$, subcoriaceous, drying green to dark green, base cuneate to slightly rounded, apex acute to abruptly acuminate; abaxial surface: midrib puberulous, secondary veins $3-5$ pairs, obscure to invisible, ascending at an angle of c. $45^{\circ}$, glabrous to puberulous, venation obscure to invisible; abaxial surface glabrous; adaxial surface glabrous. Inflorescences terminal on the apex of short side shoots, (1-)3-7-flowered, usually simple cymes, sessile to shortly pedunculate; peduncle, if present, $<0.1-0.3 \mathrm{~cm}$ long, glabrous to puberulous; bracts and bracteoles absent. Flowers imperfectly known (only buds seen), pedicellate; pedicel 0.5-2 mm long. Calyx (incl. hypanthium) 2-4 by $1.5-3.5 \mathrm{~mm}$, glabrous, calyx lobes deltate to triangular, $(0.5-) 2-4$ by $0.5-1 \mathrm{~mm}$, glabrous. Corolla imperfectly known (only buds seen), c. 3 by $2-2.5 \mathrm{~mm}$, external and internal surfaces glabrous, corolla lobes c. $1 \mathrm{~mm}$ long. Stamens: anthers $0.2-0.5 \mathrm{~mm}$ long; filaments $0.3-0.5(-0.8) \mathrm{mm}$ long. Style $0.7-1.2 \mathrm{~mm}$ long. Fruit $5.5-7$ by $4-5$ $\mathrm{mm}$, pedicel c. $2 \mathrm{~mm}$ long; calyx 1-2.5 mm long. Pyrenes $4-5.5$ by $3-4 \mathrm{~mm}$.

Distribution - Papua Barat and Papua New Guinea (incl. Sudest Island).

Habitat \& Ecology - Poorly known. Ridges; recorded with scrambling bamboo; altitude $600-2150 \mathrm{~m}$.

\section{Amaracarpus attenuatus Merr. \& L.M. Perry}

Amaracarpus attenuatus Merr. \& L.M. Perry (1946) 222. - Type: Brass 7419 (holo A; iso BM, K, L), Papua New Guinea, Oroville Camp, Fly River, Aug. 1936. 
Tree or shrub, (1.5-)2-4.5(-8) $\mathrm{m}$ high, glabrous to puberulous, hairs \pm erect to antrorse, $<0.1-0.2 \mathrm{~mm}$ long, brown; axillary brachyblasts present; leaves regularly arranged in the same plane, but not close together, forming flat but irregular shaped tiers (in outline). Branchlets 1.5-3.1(-4) mm diam., \pm smooth, brown, glabrous to puberulous. Stipules connate at the base to $1 / 3$ of their length, narrowly ovate to triangular, $(5-) 8-18(-24)$ by $(1-) 1.5-4.2 \mathrm{~mm}$, chartaceous to subcoriaceous, often 2-veined, \pm glabrous to puberulous (mostly margins and veins), apex deeply bifid, divided into two narrowly (often seta-like) triangular points (but appearing acute and undivided during early stages of development), seta-like points $(0.3-) 2-10(-12) \mathrm{mm}$ long, glabrous or puberulous. Leaves: petioles (3-)4-9 mm long, glabrous or puberulous; leaf blades \pm elliptic to \pm narrowly ovate, or oblong-elliptic, $(2.9-) 4.5-11.5(-13.2)$ by (1-) 2.2-4.5 $\mathrm{cm}$, chartaceous to almost subcoriaceous, usually drying green to dark green, but also greyish to grey, base cuneate to rounded, apex subcaudate to caudate, cauda (0.4-) $0.6-2.2 \mathrm{~cm}$ long; abaxial surface: midrib glabrous to puberulous, secondary veins (8-)10-14 pairs, prominent, ascending at an angle of $30-40^{\circ}$, glabrous or sometimes puberulous, venation obscure to manifest; abaxial surface glabrous; adaxial surface glabrous. Inflorescences axillary in the first or second leaf pair or terminal on axillary brachyblasts (near-axillary), (1-)3-6(-8)-flowered simple cymes or few-branched simple (compound) cymes, pedunculate; peduncle $(0.1-) 1.2-2.7 \mathrm{~cm}$ long, glabrous to puberulous; second order inflorescence branches present or absent, if present $0.3-1.5$ $(-5) \mathrm{cm}$ long; bracts 2 per peduncle or inflorescence branch opposite, narrowly triangular to linear, 1.5-2.4 mm long, sometimes fallen; bracteoles 2 per flower, linear, (0.3-)0.7-1 mm long, or absent. Flowers sessile or pedicellate; pedicel, if present 0.5-2 $\mathrm{mm}$ long. Calyx (incl. hypanthium) $1.5-3.5$ by $1.5-3.5 \mathrm{~mm}$, glabrous, calyx lobes deltate to triangular, $(0.5-) 0.7-1.1$ by $0.4-0.5 \mathrm{~mm}$, glabrous. Corolla $1.4-1.7(-2.1)$ by $1.5-4.5 \mathrm{~mm}$, external surface glabrous, internal surface with a ring of hairs, corolla lobes $0.5-0.7$ by $1-2.8 \mathrm{~mm}$. Stamens: anthers c. $0.6 \mathrm{~mm}$ long; filaments c. $0.5 \mathrm{~mm}$ long. Style $1.5-2.8 \mathrm{~mm}$ long. Fruit $5-8$ by $3-3.4 \mathrm{~mm}$, pedicel, if present $0.5-2 \mathrm{~mm}$ long; calyx 1-1.5 mm long, or falling. Pyrenes $5.2-6.4$ by $2.5-4.1 \mathrm{~mm}$.

Distribution - Papua Barat, Papua New Guinea (incl. Goodenough Island, Fergusson Island (Milne Bay), and Solomon Islands (incl. Rennell and Santa Cruz Islands)).

Habitat \& Ecology - Riverbanks, swampy ground and edges of swamps, but also on well-drained substrates, ravines, ridges, and coastal escarpments; recorded with Bombax spp., Celtis spp., Chisocheton spp., Intsia spp., Pometia spp. and Quercus spp.; substrate: clays and marls; locally common; altitude (30-)250-1900(-2450) m.

Note - The stipule of A. attenuatus is divided into two narrowly triangular points, which seem to divide deeper (often into two setae-like long points) as the stipule matures. Quite often the immature (partially developed) stipules of this species appear to be undivided. The stipule of A. attenuatus can sometimes resemble A. heteropus, although closer inspection reveals that the latter has two distinct needle-like setae.

\section{INSUFFICIENTLY KNOWN SPECIES}

Amaracarpus floribundus and A. nouhuizii are only known from their types. In each case the type specimen consist of material either in bud or at the early stages of flower- 
ing. There is no floral material available for dissection, and fruits of both species are unknown. The stipules of these species strongly suggest Amaracarpus, as they possess two prominent setae, but the inflorescences are terminal on well-developed side shoots, more akin to Psychotria. On the basis of the material presently available it seems that A. floribundus and A. nouhuzii (see below) might belong in Amaracarpus but mature flowers and fruits are needed before a full assessment can be made. It seems likely that these two species may be very closely related and possibly conspecific.

\section{Amaracarpus floribundus Valeton}

Amaracarpus floribundus Valeton (1927) 116. - Type: Pulle 282 (lectotype BO, selected here; isolectotypes K, L, U), [Papua Barat], Beaufort River, 80 m, Nov. 1912.

\section{Amaracarpus nouhuizii Valeton}

Amaracarpus nouhuizii Valeton (1927) 115. - Type: Römer 620 (lectotype L, selected here; isolectotype BO), Nova Guinea neerlandica meridionalis [Papua Barat], Kuskushügel, c. 100 m, 1909-1910.

\section{UNKNOWN SPECIES - SPECIES INCOGNITAE}

This section contains Amaracarpus names for which no type (or other original material) has been seen, and which cannot be placed using the author's descriptions. Most of these taxa are described by Valeton, based on Ledermann collections. All of these types were presumably held at Berlin (B), but later destroyed. It seems that there were no duplicates of these specimens and therefore, at least at the present time, we have no option but to place these names in Species Incognitae. Other researchers (e.g. Sohmer, 1988) have also reached the conclusion that the only set of Ledermann collections were held at Berlin and later destroyed.

\section{Amaracarpus braunianus (Warb.) Valeton}

Amaracarpus braunianus (Warb.) Valeton (1911) 501; (1927) 124. - Litosanthes brauniana Warb. (1891) 441; K. Schum. \&. Lauterb. (1901) 585. - Syntypes: Warburg 21445 (B†), NNG, Sattelberg, Gipfelwald; ibid. Hellwig $520(\mathrm{~B} \dagger)$.

\section{Amaracarpus ledermannii Valeton}

Amaracarpus ledermannii Valeton (1927) 125. - Syntypes: Ledermann 11861 (holo B $\dagger$ ), NNG, Schraderberg (Kais. Augusta-Station), 2070 m, 31 May 1913; Ledermann 12216 (holo B †), ibid., 12 June 1913.

\section{Amaracarpus montanus Valeton}

Amaracarpus montanus Valeton (1927) 119. - Type: Ledermann 11954 (holo B $\dagger$ ), Südöstl. NeuGuinea [Papua New Guinea], Schraderberg, 2070 m, 5 June 1913.

\section{Amaracarpus rhombifolius Valeton}

Amaracarpus rhombifolius Valeton (1927) 117. - Type: Ledermann 7407 (holo B $\dagger$ ), Nordöstl. NeuGuinea [Papua New Guinea], Pfingstberg (Kais. Augustafluss), 1-300 m, 25 May 1912. 


\section{Amaracarpus syzygifolius Valeton}

Amaracarpus syzygifolius Valeton (1927) 115. - Type: not designated by Valeton (1927; type unknown, ?B $\dagger$ ).

\section{Amaracarpus trichocalyx Valeton}

Amaracarpus trichocalyx Valeton (1927) 122. - Type: Ledermann 12793 (holo B $\dagger$ ), Nordöstl. NeuGuinea [Papua New Guinea], Felsspitze, 10 Aug. 1913.

\section{EXCLUDED SPECIES}

31. Amaracarpus caudatus Ridl. (1920) 143. - Type: Wray 670 (holo K), Malaysia, Perak, Birch's Hill, Taiping Hills, Aug. 1885. = Lasianthus, possibly L. lowianus King \& Gamble.

32. Amaracarpus giluwensis P. Royen (1983) 2686. - Type: Schodde 1869 (holo K; iso L), Papua New Guinea, western summit grasslands of Mt Giluwe, Southern Highlands District, c. 10,000 ft [3050 m], 16 Aug. 1961. = Psychotria (no combination yet proposed).

33. Amaracarpus longifolius Elmer (1906) 1. - Type: Merrill 4000 (holo ?PNH; iso K, P, US), Philippines, Atimonan, Province of Tayabas, Luzon, March 1905. = Psychotria linearis Bartl. ex DC.

34. Amaracarpus montisstellaris P. Royen (1983) 2701. - Type: Veldkamp 6319 (holo L), Papua New Guinea, Star Mts, W Sepik, Camp 2, Tel Basin, 3000 m, 5 March 1975. = Psychotria (no combination yet proposed).

35. Amaracarpus muscifer A.C. Sm. (1946) 321. - Type: Smith 1646 (holo GH; iso K, NY, P), Fiji, Vanau Levu, Mbua, Navotuvotu, summit of Mt Seatura, 830 m, 27 April 1934. = Psychotria s.1. (no combination yet proposed).

Note - Amaracarpus muscifer has terminal inflorescences, 5-merous flowers, and lacks the horizontal branching pattern and distinct dorsiventrality of Amaracarpus (e.g. see Smith, 1988: 262, f. 99c). The morphology is generally more in the direction of Dolianthus, although it is clearly not a member of this genus. Lack of available flowers and fruits for dissection means that a full appraisal of this species cannot be made at the present time. Amaracarpus muscifer is clearly not a species of Amaracarpus, however, and we provisionally place this species in Psychotria s.l.

36. Amaracarpus saxicola (Ridl.) Ridl. (1920) 143.

Saprosma saxicola Ridl. (1912) 22. - Type: Ridley 11884 (holo K), Malaysia, Perak, Bukit Kamuning, Feb. 1904.

Note - Amaracarpus saxicola has terminal inflorescences, stipules with three to five distinct teeth, and blue fruits, characters which support its original position in the genus Saprosma. 
37. Amaracarpus subcaudatus Merr. \& L.M. Perry (1946) 224. - Type: Brass 12761 (holo A; iso L), Irian Jaya [Papua Barat], 6 km SW of Bernhard Camp, Idenburg River, 1200 m, Feb. 1939. = non Amaracarpus, probably Psychotria s.1.

Note - Amaracarpus subcaudatus appears to be a member of Psychotria s.1., but until more material of this species is available it cannot be confidently assigned to a genus. We have rejected it from Amaracarpus on the basis that it lacks the horizontal branching pattern and distinct dorsiventrality of other Amaracarpus species; the stipule is distinctly bifid; the inflorescences are terminal (on side shoots and main branches); and the flowers are 4- or 5-merous. In addition, most species of Amaracarpus possess abbreviated side shoots with much reduced leaves, a character not present in A. subcaudatus. The pyrenes of A. subcaudatus are of the type found in many members of the Psychotrieae Pacific Clade (sensu Andersson, 2002), including Amaracarpus and Dolianthus. The pyrenes have marginal preformed germination slits (PGSs) and non-ruminate (entire) endosperm. We have not been able to check for the presence of an ethanol soluble seed coat pigment (SCP), a feature present in many Psychotria species, including those previously associated and often confused with Amaracarpus (e.g. P. mariana Bartl. ex DC., P. hombroniana (Baill.) Fosberg s.1.). All Amaracarpus species lack an ethanol soluble pigment in the seed coat (SCP negative).

38. Amaracarpus torricellensis Valeton (1927) 123. - Type: Schlechter 20303 (holo B†; iso K), Nordöstl. Neu-Guinea [Papua New Guinea], Torricelli-Gebirge, 700 m, Sept. 1909. = non Amaracarpus, ?gen. nov.

Note - Amaracarpus torricellensis possesses several characteristics that set it apart from Amaracarpus, and there is the possibility that it represents a new genus. Amaracarpus torricellensis has a horizontally branched habit (like Amaracarpus); leaves which smell foetid when crushed (not reported in Amaracarpus); terminal and/or nearaxillary inflorescences (the latter like Amaracarpus); relatively large, white, 5-merous flowers; anthers inserted above ring of corolla throat hairs (like Dolianthus); a style that has two opposite longitudinal furrows running down its length (the two halves of the style being easily pulled apart); a stigmatic surface comprising two large flattened membranous lobes, and pyrenes like Amaracarpus but with PGSs more or less on the adaxial surface rather than margins. The stipules of $A$. torricellensis are generally like those of Amaracarpus (caducous; leaving a simple naked scar, sheathing and connate for c. $1 / 2$ their length or slightly more); the stipule apex is acute to obtuse, without setae or other appendages.

\section{PREVIOUSLY EXCLUDED SPECIES}

The above list of excluded species contains only those excluded by us. Previously, Fosberg \& Sachet (1991) transferred 13 Pacific Amaracarpus to Psychotria, and Davis \& Bridson (2001) transferred 13 species of Amaracarpus to Dolianthus. The Appendix includes the details of previously excluded species, within a checklist of all published Amaracarpus names. 


\section{MISCELLANEOUS NOTES}

Note 1 - Since the revision of Dolianthus C.H. Wright (Davis \& Bridson, 2001) we have become aware of the genus Melachone, published by Gilli (1980). The only species, M. microphylla Gilli, is clearly a synonym of $D$. subalpinus (P. Royen) A.P. Davis. Melachone has been previously treated as a synonym of Amaracarpus (e.g. Robbrecht, 1988).

Dolianthus C.H. Wright (1899) 106.

Melachone Gilli (1980) 459. - Type: Melachone microphylla Gilli.

Dolianthus subalpinus (P. Royen) A.P. Davis in A.P. Davis \& Bridson (2001) 425. Melachone microphylla Gilli (1980) 460. - Type: Gilli 338 (holo W), [Papua New Guinea], Südhang des Mt Wilhelm, 3300 m, 1 Feb. 1974.

Note 2 - It has been brought to our attention (C. Barker, pers. comm.) that we made an error in the citation of Amaracarpus montiswilhelmii P. Royen in our revision of Dolianthus (Davis \& Bridson, 2001: 431), by adding a hyphen between montis and wilhelmii (as 'D. montis-wilhelmii'). The ICBN does not mention adding hyphens only deleting them, as errors to be corrected, even though having a hyphen between montis and the genitive name of the mountain is the usual practice. The correct name for this species is D. montiswilhelmii (P. Royen) A.P. Davis; Van Royen's original spelling (as 'montiswilhelmi') is an orthographical error.

\section{ACKNOWLEDGEMENTS}

We would like to thank the staff at the herbaria listed in Materials and Methods for organising and sending loans of herbarium material. We are grateful to S. Dressler for selecting loan material in SE Asian herbaria, M. Coode for assistance with geography and place names, C.M. Wilmot-Dear for her help with Latin, and J. Wessendorp for his drawing of A. pubescens.

A.P. Davis undertook this study as part of a Royal Society fellowship under the European Science Exchange Programme, and would like to acknowledge The Royal Society for their generous support. The host institute for the European Science Exchange Programme was the Universiteit Leiden branch of the Nationaal Herbarium Nederland, The Netherlands. A.P. Davis would like to thank the Director and staff at the Nationaal Herbarium Nederland for their support and assistance over the duration of the fellowship.

We would also like to thank Prof. Elmar Robbrecht and an anonymous reviewer for carefully reviewing an earlier version of this paper.

\section{REFERENCES}

Andersson, L. 2002. Relationships and generic circumscription in the Psychotria complex (Rubiaceae, Psychotrieae). Syst. Geogr. Pl. 72: 167-202.

Andrews, C.W. 1900. A monograph of Christmas Island, Indian Ocean. British Museum Trustees, London.

Backer, C.A. \& R.C. Bakhuizen van den Brink Jr. 1965. Rubiaceae. Flora of Java 2: 274-357. Noordhoff, Groningen.

Baker, J.G. 1877. Flora of Mauritius and the Seychelles. Reeve \& Co., London.

Blume, C.L. 1826. Bijdragen tot de Flora van Nederlandsch Indië. Ter Lands Drukkerij, Batavia. 
Davis, A.P. \& D.M. Bridson. 2001. A taxonomic revision of the genus Dolianthus (Rubiaceae). Blumea 46: 421-446.

Davis, A.P. \& D.M. Bridson. In press. The delimitation of Amaracarpus and Dolianthus, and comments on the generic circumscription of Pacific Psychotrieae (Rubiaceae). Syst. Bot.

Davis, A.P., D.M. Bridson, C. Jarvis \& R. Govaerts. 2001. The typification and characterization of the genus Psychotria L. (Rubiaceae). Bot. J. Linn. Soc. 135: 35-42.

Du Puy, D., I.R.H. Telford \& A.E. Orchard. 1993. Rubiaceae. Flora of Australia 50 (Ocean Islands 2): 392-405. Australian Government Publishing Service, Canberra.

Elmer, A.D.E. 1906. Philippine Rubiaceae. Leafl. Philipp. Bot. 1: 1-41.

Elmer, A.D.E. 1911. New and noteworthy Rubiaceae. Leafl. Philipp. Bot. 3: 971-1046.

Elmer, A.D.E. 1915. Two hundred twenty six new species - II. Leafl. Philipp. Bot. 8: 2719-2883.

Fosberg, F.R. \& M.-H. Sachet. 1991. Studies in Indo-Pacific Rubiaceae. Allertonia 6: 191-278.

Friedmann, F. 1994. Flore des Seychelles, Dicotylédones. Orstom, Paris.

Gibbs, L.S. 1917. A contribution to the phytogeography and flora of the Arfak Mountains, etc. Taylor \& Francis, London.

Gilli, A. 1980. Beiträge zur Flora von Papua New Guinea II. Dicotyledones. Ann. Naturhist. Mus. Wien 83: 417-474.

Hemsley, W.B. 1906. Neoschimpera heterophylla. Hooker's Icon. Pl. ser. 4, 9: t. 2810.

IUCN. 2001. IUCN Red List Categories: Version 3.1. Prepared by the IUCN Species Survival Commission. Gland, Switzerland \& Cambridge, United Kingdom.

Merrill, E.D. \& L.M. Perry. 1946. Plantae Papuanae Archboldianae, XVII. J. Arnold Arbor. 27: $193-233$.

Miquel, F.A.W. 1857. Rubiaceae. Flora van Nederlandsch Indië 2: 129-357. Van der Post, Amsterdam/Utrecht.

Miquel, F.A.W. 1869. Ecologe Rubiacearum archipelagi Indici. Ann. Mus. Bot. Lugd.-Bat. 4: $179-262$.

Moore, S. 1923. H.O. Forbes's New Guinea plants. Gamopetalae. J. Bot. 61, Suppl.: 23-39.

Nepokroeff, M., B. Bremer \& K.J. Systma. 1999. Reorganization of the genus Psychotria and tribe Psychotrieae (Rubiaceae) inferred from ITS and rbcL sequence data. Syst. Bot. 24: 5-27.

Puff, C. \& K.M. Wong. 1993. A synopsis of the genera of Rubiaceae in Borneo. Sandakania 2: $13-34$.

Ridley, H.N. 1912. New and rare Malayan plants (Series VI). J. Straits Branch Roy. Asiat. Soc. 61: $1-43$.

Ridley, H.N. 1920. New and rare plants from the Malay Peninsula. J. Fed. Malay States Mus. 10: $128-156$.

Robbrecht, E. 1988. Tropical woody Rubiaceae. Opera Bot. Belg. 1: 1-271.

Schumann K.M. \& K.A.G. Lauterbach. 1901 ('1900’). Die Flora der Deutschen Schutzgebiete in der Südsee. Gebrüder Borntraeger, Leipzig.

Smith, A.C. 1946. Studies of Pacific island plants, V: New and noteworthy flowering plants from Fiji. J. Arnold Arbor. 27: 319-322.

Smith, A.C. 1988. Flora Vitiensis Nova - A new Flora of Fiji, Vol. 4. SB Printers, Honolulu.

Sohmer, S.H. 1988. The nonclimbing species of the genus Psychotria (Rubiaceae) in New Guinea and the Bismarck Archipelago. Bishop Mus. Bull. Bot. 1: 1-339.

Valeton, T. 1909-1914. Rubiaceae. Nova Guinea 8, 3 (atlas): pl. 125-129.

Valeton, T. 1911. Rubiaceae. Nova Guinea 8, 1: 437-519.

Valeton, T. 1912. Rubiaceae. Nova Guinea 8, 4: 755-775.

Valeton, T. 1927. Die Rubiaceae von Papuasien II. Bot. Jahrb. Syst. 61: 32-163.

Van Royen, P. 1983. The alpine flora of New Guinea. Vol. 4. Cramer, Vaduz.

Van Steenis-Kruseman, M.J. 1950. Flora Malesiana Vol. 1, Malaysian Plant Collectors and Collections. Noordhoff-Kolff N.V., Djakarta.

Warburg, O. 1891. Beiträge zur Kenntnis der papuanischen Flora. Bot. Jahrb. Syst. 13: 230-455.

Wernham, H.F. 1916. Report on the botany of the Wollaston Expedition to Dutch New Guinea, 1912-1913. Rubiaceae. Trans. Linn. Soc. London, Bot. 9: 66-79.

Wright, C.H. 1899. Flora of British New Guinea. Dolianthus. Kew Bull. [1899]: 106. 


\section{IDENTIFICATION LIST}

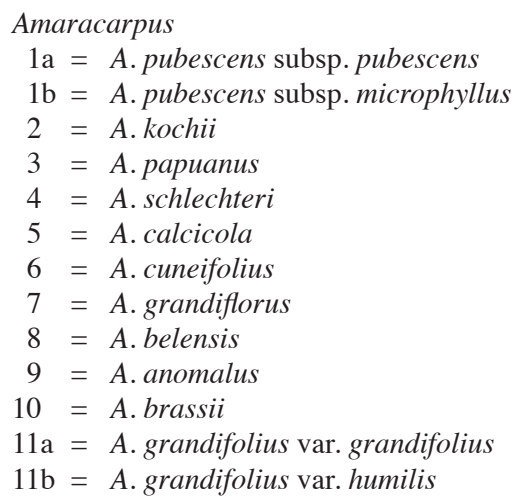

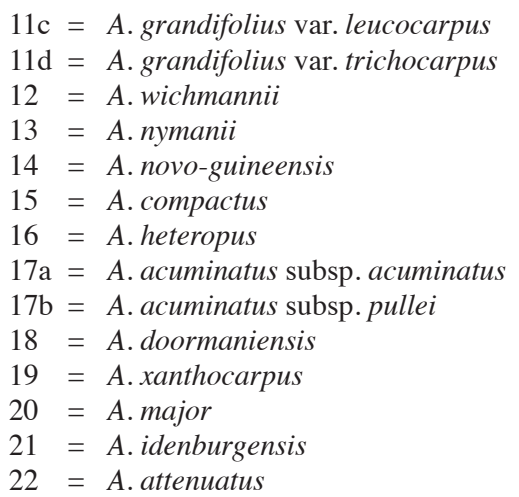

Adelbert 457: 1a - Argent 87184: 7.

Backer 37250: 1a - Baker 905: 14 - Barker 144: 2; 66841: 11b - Benjamin 67928: 22 - Bhargava 2405: 1a; 4153: 1a - Bloembergen 4740: 1a - Brass 1039: 11d; 2955: 11a; 3876: 11a; 4133: 15; 6741: 4; 7419: 22; 8849: 5; 10522: 15; 10823: 10; 11055: 8; 12393: 19; 12674: 21; 12861 : 19; 13863: 4; 13864: 16; 23785: 13; 24011: 13; 24447: 11a; 24595: 22; 24629: 22; 24985: 13; 25404: 11a; 27150: 11a; 27837: 21; 28012: 5; 29231: 11a; 29281: 11a; 30876: 17a; 32095: 3; 32677: 11a - Brinkman 623: 1a - Burwalda 4283: 1a.

Carr 12544: 22; 13591: 15; 13722: 15; 13902: 22; 14064: 22; 15015: 22; 15215: 15; 15397: 22; 15703 : 22 - Charkraborty 1205: 1a; 2022: 1a - Clemens 1040: 14; 3057: 14; — Clemens \& Clemens 768: 20; 1064: 11a - Clunie et al. 63513: 11b; 63516: 22 - Conn, Pattison, Sands \& Wood 66273: 22 - Coode 5842: 1a; 5942: 1b; 5971: 1a; 7998: 20; 32698: 11a - Craven \& Schodde 1038: 14; 1259: 11b - Croft \& Gideon 71587: 6 - Croft \& Lelean 34947: 15 - Croft et al. 65023: 15; 68624: 16; 68777: 11a; 68889: 11b; 68916: 11b - Cruttwell 507: 13; 605: 11d; 710: 13.

Danser 3299: 1a - Darbyshire 1001: 11d - Davis 680: 2; 778: 6; 838: 12 - De Bruyn 47: 16; 169: 16 - De Voogd 1837: 1a - Donunaba 49111: 11a - Drozod 150: 5.

Edwards 4127: 2 - Elbert 3217: 1b; 3752: 1a; 3791: 1a; 3813: 1a - Elmer 10737: 1b - Eyma 2368: 7; 4283: 1a; 4674: 9; 5047: 9.

Forbes 657: 17a; 1569: 1a - Foreman 48150: 20 - Frodin 26799: 11b.

Gafui et al. 14808: 22; 14852: 22; 16452: 11a - Gardiner 25: 1a - Gideon 77132: 11b - Gillison 25325: 11a - Gjellerup 264(721): 16; 327: 16 - Gray 8103: 11b.

Hartley 9804: 11c; 9849: 11a; 10553: 11a; 11091: 11a; 11410: 11a; 11918: 11d; 12225: 11c - Hellwig 231: 14; 523: 14 - Henty 10618: 8; 10640: 11a; 11955: 11a; 13670: 11d; 14708: 11a; 14851: 22; 16864: 11d; 49917: 11b - Henty \& Coode 29182: 11b; 29187: 11a - Henty \& Frodin 27337: 11a - Henty, Isgar \& Galore 41685: 17a - Henty \& Lelean 49945: 11a - Henty, Ridsdale \& Galore 33018: 4 - Hiepko \& Schultze-Motel 1306: 15 - Hoogerwerf 185: 1a - Hoogland 4475: 11a - Hoogland \& Craven 10667: 2 - Horne 252: 1a - Horsfield 43: 1a - Hunt 2982: 11d; 3050: 11d; 3055: 11d.

Iboet 493: 1a - Isles \& Vinas 34468: 11a.

Jacobs 8876: 2 - Jeffrey, Moulinie \& Zeila 798: 1a - Jeffrey \& Zeila 823: 1a - Jensen 115: 1a - Johansson, Nybom \& Riebe 204: 1a - Johns 8821: 20; 9807: 3; 10428: 2.

Kairo 114: 11a; 231: 11a - Kajewski 1541: 11a; 2394: 11a - Kalkman 122: 16; 3765: 16 - Kanehira \& Hatusima 11862: 3; 12092: 17b; 13098: 12; 13258: 12 - Katik 37980: 11a; 46861: 11c; 78100: 11b - Katik \& Taho 56361: 11a - Katik et al. 70873: 21 - Kato, Sunarno \& Akiyama 3664: $1 \mathrm{~b}$ - Kato, Ueda \& Fanani 11885: 7; 13441: 8 - Kerenga 56431: 16; 56512: 17a - Kerr 18255: 1a - Koch 16: 2; 552: 2 - Koie \& Olsen 1241: 11c; 1580: 11c - Koorders 18607b: 1a; 18609b: 1b; 18719b: 1b; 27535b: 1a; 38976b: 1a; 39165b: 1a - Koster 4335: 12; 10762: 14; 13570: 6; 13572: 16 - Kostermans 2695: 12; 7861: 11a; 18259: 1a; 18774: 1a; 19180: 1a - 
Kostermans, Kuswata, Soegeng \& Soepadmo 135: 1a; 296: 1a - Kostermans \& Soegeng 261: 16; 338: 16 - Kostermans \& Wirawan 655: 1a; 836: 1a - Kurz 26: 1a.

Lam 544: 17b; 1084: 16; 1482: 18; 1990: 18; 2813: 1a - Lauterbach 113: 11c; 685: 11a; 925: 11c; 996: 11c; 1148: 11a; 1207: 11a; 2113: 11c - Lütjeharms 4837: 1a.

Mangen 299: 10; 2027: 15 - Mauriasi 8638: 11a - Mauriasi et al. 15869: 11a; 16624: 22; 17123: 22; 17159: 22 - McDonald \& Ismail 3814: 16 - McKee 1781: 5; 1828: 5 - Meijer \& Muchtar 10632: 1a - Moll 13000: 16.

Nakisi \& Mauriasi BSIP 8065: 11d - Native collector 5615: 11d - Nedi 282: 1b - Nyman 479: 14.

Paijmans 1438: 11a - Pleyte 206: 1b; 663: 22; 1056: 12 - Powell 332: 1a; 332a: 1a - Proctor 4371: 1a - Pulle 284: 6; 1219: 17b - Pullen 1457: 11a; 1458: 17b; 1821: 22; 8355: 11d.

Ridley 33: 1a - Ridsdale 33909: 11b - Ridsdale \& Lavarack 30639: 11a - Rutten 249: 1b; 1973 : 8 .

Saki \& Wawikiak 4663: 11a - Sands 797: 11a; 798: 11a; 1020: 11a; 6131: 12 - Sands, Pattison \& Wood 2623: 12 - Sands, Pattison, Wood \& Kene 2066: 11a - Sarip 213: 1a - Saunders 174: 13 - Sayers 13208: 16; 13292: 11a - Schlechter 14153: 11a; 14237: 11a; 16090: 5; 16186: 11a; 16550: 4; 16614: 11a; 16702: 11a; 17221: 20; 17368: $11 \mathrm{~b}$ - Schmutz 374: 1a; 1001: 1a; 2876: 1a - Schodde 3306: 16 - Schwabe 53: 1a - Smitinand \& Sleumer et al. 1235: 1a - Soegeng Reksodihardjo 504: 4 - Sohmer 75047: 22 - Stevens 50412: 22; 51118: 17a - Stone 2363: 11a - Streiman 28740: 13; 53832: 5 - Streiman \& Kairo 39204: 16; 39234: 2; 44439: 11a - Streseman 157: 8 .

Takeuchi 6285: 18; 8926: 11a - Takeuchi \& Damas 4399: 11b - Takeuchi \& Kulang 11318: 22 - Teijsmann 12774: 1a - Teona 4858: 11a - Thomasset 181: 1a - Toxopeus 307: 1a.

Ueda, Okamato \& Mahjar 3910: 7 - UPNG 1324: 13 - Utteridge 126: 2; 453: 2.

Van Balgooy \& Van Setten 5665: 1a - Van Leeuwen 9136: 16; 9501: 16; 9718: 16; 10764: 6; 11168: 16; 11321: 16 - Van Royen 3041: 12; 4120: 5; 10948: 11d - Van Royen \& Sleumer 6010: 8; 6204: 16; 6345: 17a; 7036: 12 - Van Steenis 7684: 1a; 18157: 1a - Veldkamp 6688: 15 - Verheijen 2954: 1a; 4084: 1a - Versteeg 1591: 3; 1680: 6 - Vinas \& Wiakabu 59524: 15 — Vink 8412: 2; 8469: 17b; 15340: 16 - Von Römer 446: 6.

Webster \& Hildreth 15096: 11b - Whitmore 1306: 11d; 1335: 11a - Wichmann (leg.Atasrip) 6: 12

- Womersley 5324: 15; 48659: 11a - Womersley \& Katik 43994: 13 - Woods 2240: 14.

Zollinger 790: 1a; 796: 1a; 2334: 1a.

\section{INDEX}

Accepted names are in roman type; new combinations and new species in bold; synonyms, insufficiently known and excluded species in italics.

\author{
Amaracarpus Blume [p. 28] \\ acuminatus S. Moore 17 \\ subsp. acuminatus $17 \mathrm{a}$ \\ subsp. pullei (Valeton) A.P. Davis $17 \mathrm{~b}$ \\ anomalus Wernham 9 \\ apoensis Elmer 1b \\ atrocarpus Merr. \& L.M. Perry 4 \\ attenuatus Merr. \& L.M. Perry 22 \\ belensis Merr. \& L.M. Perry 8 \\ brachypus Merr. \& L.M. Perry 11 \\ brassii Merr. \& L.M. Perry 10 \\ braunianus (Warb.) Valeton 25 \\ var. major Valeton 20 \\ calcicola Merr. \& L.M. Perry 5 \\ caudatus Ridl. 31 \\ compactus Merr. \& L.M. Perry 15
}

\author{
(Amaracarpus) \\ corymbosus Valeton 16 \\ cuneifolius Valeton 6 \\ doormaniensis Valeton 18 \\ floribundus Valeton 23 \\ forbesii Valeton 17 \\ giluwensis P. Royen 32 \\ grandicalyx Valeton 11 \\ grandiflorus A.P. Davis 7 \\ grandifolius Valeton 11 \\ var. grandifolius 11a \\ var. humilis (Valeton) A.P. Davis $11 \mathrm{~b}$ \\ var. leucocarpus (Lauterb. \& K. Schum.) \\ A.P. Davis $11 \mathrm{c}$ \\ var. trichocarpus (Merr. \& L.M. Perry) \\ A.P. Davis $11 \mathrm{~d}$
}




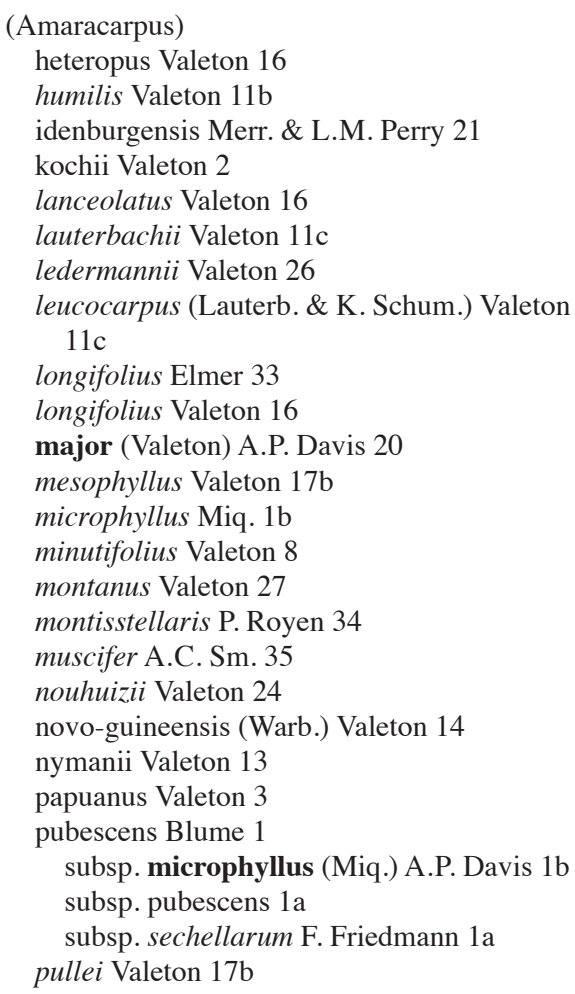

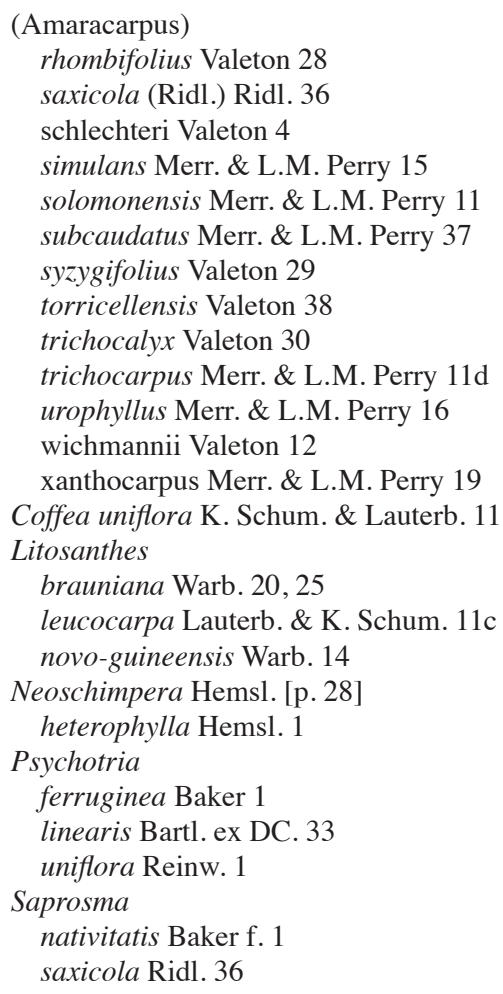

rhombifolius Valeton 28

saxicola (Ridl.) Ridl. 36

simulans Merr. \& L.M. Perry 15

solomonensis Merr. \& L.M. Perry 11

subcaudatus Merr. \& L.M. Perry 37

syzygifolius Valeton 29

torricellensis Valeton 38

trichocarpus Merr. \& L.M. Perry 11d

urophyllus Merr. \& L.M. Perry 16

wichmannii Valeton 12

xanthocarpus Merr. \& L.M. Perry 19

Coffea uniflora K. Schum. \& Lauterb. 11

Litosanthes

brauniana Warb. 20, 25

leucocarpa Lauterb. \& K. Schum. 11c

novo-guineensis Warb. 14

heterophylla Hemsl. 1

Psychotria

linearis Bartl. ex DC. 33

uniflora Reinw. 1

nativitatis Baker f. 1

saxicola Ridl. 36 
Appendix. Alphabetical checklist of all published Amaracarpus names. Accepted names in bold.

\begin{tabular}{ll}
\hline All names & Accepted name \\
\hline
\end{tabular}

Amaracarpus acuminatus S. Moore Amaracarpus acuminatus S. Moore subsp. acuminatus

Amaracarpus acuminatus S. Moore subsp. pullei (Valeton) A.P. Davis Amaracarpus anomalus Wernham Amaracarpus apoensis Elmer

Amaracarpus archboldianus Merr. \& L.M. Perry ${ }^{2}$

Amaracarpus pubescens subsp. microphyllus (Miq.) A.P. Davis

Amaracarpus atrocarpus Merr. \& L.M. Perry Amaracarpus attenuatus Merr. \& L.M. Perry Amaracarpus belensis Merr. \& L.M. Perry Amaracarpus bicolor Merr. \& L.M. Perry 2 Amaracarpus brachypus Merr. \& L.M. Perry

Amaracarpus brassii Merr. \& L.M. Perry

Amaracarpus braunianus Valeton Amaracarpus buxifolius (C.H. Wright) Merr. \& L.M. Perry 2

Amaracarpus caeruleus Merr. \& L.M. Perry ${ }^{2}$ Amaracarpus calcicola Merr. \& L.M. Perry

Amaracarpus carolinensis Valeton ${ }^{1}$

Amaracarpus carolinensis Valeton var. squarrosa Valeton ${ }^{1}$

Amaracarpus caudatus Ridl.

Amaracarpus clemensae Merr. \& L.M. Perry ${ }^{2}$

Amaracarpus compactus Merr. \& L.M. Perry Amaracarpus confertifolius Merr. \& L.M. Perry ${ }^{2}$ Amaracarpus corymbosus Valeton Amaracarpus cuneatus Valeton

Amaracarpus cuneifolius Valeton

Amaracarpus doormaniensis Valeton

Amaracarpus epiphyticus Valeton ${ }^{2}$

Amaracarpus fimbristipularis P. Royen ${ }^{2}$

Amaracarpus floribundus Valeton

Amaracarpus giluwensis P. Royen

Amaracarpus grandicalyx Valeton

Amaracarpus grandiflorus A.P. Davis

Amaracarpus grandifolius Valeton

Amaracarpus grandifolius Valeton var. grandifolius

Amaracarpus grandifolius Valeton var. humilis (Valeton) A.P. Davis

Amaracarpus grandifolius Valeton var.

leucocarpus (Lauterb. \& K. Schum.) A.P. Davis Amaracarpus grandifolius Valeton var.

trichocarpus (Merr. \& L.M. Perry) A.P. Davis Amaracarpus heteropoides Valeton ${ }^{1}$

Amaracarpus heteropus Valeton

Amaracarpus hirtellus Valeton ${ }^{1}$

Amaracarpus humilis Valeton

Amaracarpus idenburgensis Merr. \& L.M. Perry Amaracarpus kanehirae Hosok. ${ }^{1}$

Amaracarpus kraemeri Valeton ${ }^{1}$

$$
\text { A.P. Davis }
$$

Amaracarpus schlechteri Valeton

Dolianthus bicolor (Merr. \& L.M. Perry) A.P. Davis

Amaracarpus grandifolius Valeton var. grandifolius

Amaracarpus (unknown species)

Dolianthus buxifolius (C.H. Wright) A.P. Davis

Dolianthus buxifolius (C.H. Wright) A.P. Davis

Psychotria hombroniana (Baill.) Fosberg var. squarrosa (Valeton) Fosberg

Psychotria hombroniana (Baill.) Fosberg var. squarrosa (Valeton) Fosberg

Lasianthus, possibly L. lowianus King \& Gamble

Dolianthus clemensae (Merr. \& L.M. Perry) A.P. Davis

Dolianthus buxifolius (C.H. Wright) A.P. Davis Amaracarpus heteropus Valeton in error for Amaracarpus cuneifolius Valeton

Dolianthus epiphyticus (Valeton) A.P. Davis Dolianthus fimbristipularis (P. Royen) A.P. Davis Amaracarpus (insufficiently known species) Psychotria spec. (comb. ined.)

Amaracarpus grandifolius Valeton

Psychotria hombroniana (Baill.) Fosberg var. squarrosa (Valeton) Fosberg

Psychotria hombroniana (Baill.) Fosberg var. hirtella (Valeton) Fosberg

Amaracarpus grandifolius Valeton var. humilis (Valeton) A.P. Davis

Psychotria hombroniana (Baill.) Fosberg var. kusaiensis (Kaneh.) Fosberg

Psychotria hombroniana (Baill.) Fosberg var. squarrosa (Valeton) Fosberg 
Appendix (continued)

\begin{tabular}{l} 
All names \\
\hline${\text { Amaracarpus kusaiensis Kaneh. }{ }^{1}}^{\text {Amaracarpus ladronicus (Hosok.) Hosok. }{ }^{1}}$ \\
Amaracarpus lanceolatus Valeton \\
Amaracarpus lauterbachii Valeton \\
Amaracarpus ledermannii Valeton \\
Amaracarpus leucocarpus (Lauterb. \& K. Schum.) \\
$\quad$ Valeton \\
Amaracarpus longifolius Elmer \\
Amaracarpus longifolius Valeton \\
Amaracarpus macrophyllus Valeton ${ }^{1}$
\end{tabular}

Amaracarpus major (Valeton) A.P. Davis Amaracarpus malaspinae (Merr.) Kaneh. \& Hatus. ${ }^{1}$ Amaracarpus mariannensis Kaneh. ${ }^{1}$

Amaracarpus mesophyllus Valeton

Amaracarpus microphyllus Miq.

Amaracarpus montanus Valeton Amaracarpus montisstellaris P. Royen Amaracarpus montiswilhelmii P. Royen ${ }^{2}$ Amaracarpus muscifer A.C. Sm.

Amaracarpus nouhuizii Valeton Amaracarpus novo-guineensis Valeton

Amaracarpus nummatus P. Royen ${ }^{2}$

Amaracarpus nymanii Valeton

Amaracarpus papuanus Valeton

Amaracarpus pubescens Blume

Amaracarpus pubescens Blume subsp. microphyllus (Miq.) A.P. Davis

Amaracarpus pubescens Blume subsp. pubescens Amaracarpus pubescens subsp. sechellarum F. Friedmann Amaracarpus pullei Valeton

Amaracarpus rhombifolius Valeton Amaracarpus rotensis Hosok. ${ }^{1}$

Amaracarpus saxicola Ridl.

Amaracarpus schlechteri Valeton

Amaracarpus simulans Merr. \& L.M. Perry Amaracarpus solomonensis Merr. \& L.M. Perry

Amaracarpus subalpinus P. Royen ${ }^{2}$ Amaracarpus subcaudatus Merr. \& L.M. Perry Amaracarpus syzygifolius Valeton Amaracarpus torricellensis Valeton Amaracarpus trichanthus Merr. \& L.M. Perry ${ }^{2}$

Amaracarpus trichocalyx Valeton Amaracarpus trichocarpus Merr. \& L.M. Perry

Amaracarpus urophyllus Merr. \& L.M. Perry Amaracarpus vaccinioides (C.H. Wright) P. Royen Amaracarpus wichmannii Valeton Amaracarpus xanthocarpus Merr. \& L.M. Perry

Accepted name

Psychotria hombroniana (Baill.) Fosberg var. kusaiensis (Kaneh.) Fosberg

Psychotria hombroniana (Baill.) Fosberg var. ladronica (Hosok.) Fosberg

Amaracarpus heteropus Valeton

Amaracarpus grandifolius Valeton var. leucocarpus (Lauterb. \& K. Schum.) A.P. Davis

Amaracarpus (unknown species)

Amaracarpus grandifolius Valeton var. leucocarpus (Lauterb. \& K. Schum.) A.P. Davis

Psychotria linearis Bartl. ex DC.

Amaracarpus heteropus Valeton

Psychotria hombroniana (Baill.) Fosberg var. hirtella (Valeton) Fosberg

Psychotria malaspinae Merr.

Psychotria hombroniana (Baill.) Fosberg var. mariannensis (Kaneh.) Fosberg

Amaracarpus acuminatus S. Moore subsp. pullei (Valeton) A.P. Davis

Amaracarpus pubescens Blume subsp. microphyllus (Miq.) A.P. Davis

Amaracarpus (unknown species)

Psychotria spec. (comb. ined.)

Dolianthus montiswilhelmii (P. Royen) A.P. Davis

= Psychotria s.1.

Amaracarpus (insufficiently known species)

Dolianthus nummatus (P. Royen) A.P. Davis

Amaracarpus pubescens Blume subsp. pubescens

Amaracarpus acuminatus S. Moore subsp. pullei (Valeton) A.P. Davis

Amaracarpus (unknown species)

Psychotria hombroniana (Baill.) Fosberg var. hombroniana

Saprosma spec.

Amaracarpus compactus Merr. \& L.M. Perry

Amaracarpus grandifolius Valeton var. grandifolius

Dolianthus subalpinus (P. Royen) A.P. Davis

non Amaracarpus, probably Psychotria s.1.

Amaracarpus (unknown species)

non Amaracarpus, ?gen. nov.

Dolianthus trichanthus (Merr. \& L.M. Perry) A.P. Davis

Amaracarpus (unknown species)

Amaracarpus grandifolius Valeton var. trichocarpus (Merr. \& L.M. Perry) A.P. Davis

Amaracarpus heteropus Valeton

Dolianthus vaccinioides C.H. Wright

1) Transferred to Psychotria by Fosberg \& Sachet (1991).

2) Transferred to Dolianthus by Davis \& Bridson (2001). 